\title{
CARACTERÍSTICAS ESTRUTURAIS, LITOLÓGICAS E MAGMÁTICAS DA ZONA DE CISALHAMENTO DÚCTIL DO RIO TRAÍRAS, BLOCO DO COMPLEXO DE NIQUELÂNDIA, GOIÁS
}

\author{
JOSÉ A. BROD * \& HARDY JOST *
}

\begin{abstract}
STRUCTURAL, LITHOLOGIC, AND MAGMATIC CHARACTERISTICS OF THE TRAÍRAS DUCTILE SHEAR ZONE, NIQUELÂNDIA COMPLEX BLOCK, GOIÁS. The Rio Traíras shear zone, Goiás, Central Brazil zone is a ductile, dextral transcurrent, north-northeast trending, subvertical structure. Several types of upper green-schist to mid amphibolite recrystallized mylonites characterize the shear zone. Small felsic alkali-calcic to alkaline felsic plutons as well as alkaline mafic dykes intrude the mylonites. The shear zone uncouples the Niquelândia mafic-ultramafic Complex from the westerly Coitezeiro (Indaianopolis) volcano-sedimentary Sequence.
\end{abstract}

Keywords: Shear zones, granite, Niquelândia, Goias, Brazil.

\begin{abstract}
RESUMO A zona de cisalhamento denominada Rio Traíras, situada no Estado de Goiás, é uma estrutura transcprrente dextral, de natureza dúctil, com direção norte-nordeste e mergulho subvertical. Diversos tipos de milonitos generaUzadamente recristalizados, sob condições que variam entre a fácies xisto verde superior e anfibolito médio, marcam a zona de cisalhamento. Pequenos plútons félsicos alcali-cálcicos a alcalinos e diques básicos de tendência alcalina intrudem os milonitos. A zona de cisalhamento descrita desacopla o Complexo máfico-ultramáfico de Niquelândia, a leste, da Seqüência Vulcanossedimentar do Coitezeiro (Indaianopolis), a oeste.
\end{abstract}

Palavras-chaves: Zonas de cisalhamento, granito, Niquelândia, Goiás, Brasil.

INTRODUÇÃO A Zona de Cisalhamento do Rio Traíras, localizada na região de Indaianopolis, Goiás, é uma zona de desacoplamento crustal marcada por uma faixa de milonitos com 3 a 4 km de largura, direção nor-nordeste e mergulho subvertical. Esta estrutura é a zona de contato entre o Complexo de Niquelândia, a leste, e a Seqüência Vulcanossedimentar de Indaianopolis (sensu Nascimento et al 1981), redefinida para Sequiência Coitezeiro por Brod (1988), a oeste (Fig. 1). Neste trabalho, os aspectos geométricos, petrográficos e estruturais da zona de cisalhamento e dos eventos ígneos associados, bem como as características petroquímicas e o significado geotectônico dos últimos, são descritos e interpretados.

O BLOCO DE NIQUELÂNDIA O Bloco de Niquelândia é um segmento crustal localizado na região central do Estado de Goiás, com forma elíptica (Fig. 1), tendo aproximadamente $50 \mathrm{~km}$ segundo a direção nordeste-sudoeste e 28 $\mathrm{km}$ segundo sudeste-noroeste. O seu contorno é demarcado por falhas de empurrão com vergências, como mostrado na figura 1 . O bloco é transversalmente recortado por diversas falhas direcionais de direção NW e traço curto, grosseiramente dispostas em leque. Litologicamente, o bloco consiste de duas associações de rocha compreendendo o Complexo de Niquelandia a leste e a Seqüência Vulcanossedimentar Coitezeiro (Indaianópolis) a oeste.

O Complexo de Niquelândia é um corpo máfico-ultramáfico de idade presumivelmente arqueana ou proterozóica inferior. Dados acerca da geologia geral, petrologia e geoquímica do complexo são apresentados em diversos artigos, destacando-se os de Danni et al. (1982) e Rivalenti et al. (1982). O complexo compreende uma faixa ultramáfica oriental, com cerca de 2 a $3 \mathrm{~km}$ de largura, considerada como a porção estratigraficamente inferior, sotoposta por uma faixa com 6 a $8 \mathrm{~km}$ de largura de rochas básicas. A porção mais superior consiste de anortositos e gabros, marginados a oeste por uma franja com 1 a 1,5 km de largura de anfibolitos finos. A gênese do Complexo é ainda controversa. Almeida (1968) e Angeiras (1968) o interpretaram como um cinturão serpentinítico. Outros o interpretaram como parte de uma associação ofiolítica (Costa \& Angeiras 1971) ou proto-ofiolítica (Danni \& Leonardos 1981, Danni et al 1982), ou, alternativamente, como um complexo estratiforme derivado de magmas gabróicos (Barbosa 1968, Rivalenti et al, 1982).

As associações minerais da porção oriental do Complexo são caracterizadas pela presença de "hiperstênio", diopsídio e plagioclásio cálcico, em uma textura poligonal, ao passo que na porção ocidental predominam homblenda, granada e plagioclásio. Segundo Danni \& Leonardos (1982), as associações minerais encontradas no complexo são indicativas de metamorfismo em fácies granulito e anfibolito, respectivamente nas porções leste e oeste. Para Rivalenti et al (1982), estes minerais são magmáticos.

A Seqüência Vulcanossedimentar Coitezeiro (Indaianópolis) consiste de uma associação de xistos e filítos que, segundo Brod (1988), compreende uma porção basal com metavulcânicas básicas até ácidas, de filiação alcalina, e uma porção de topo com metapelitos intercalados, de eventuais níveis de formações ferríferas e tufos ácidos. As paragêneses minerais desta seqüência indicam condições de metamorfismo da fácies xisto verde, atingindo no máximo a zona da biotita.

As relações entre o Complexo Máfico-ultramáfico de Niquelandia e a Seqüência Vulcanossedimentar Coitezeiro dependem da interpretação da natureza do primeiro. Assim, para uma estrutura ofiolítica, o conjunto representaria uma parte de crosta oceânica onde, de leste para oeste, a seção de intrusivas diferenciadas daria lugar aos basaltos de fundo oceânico (anfibolitos finos da borda oeste). Estes estariam 


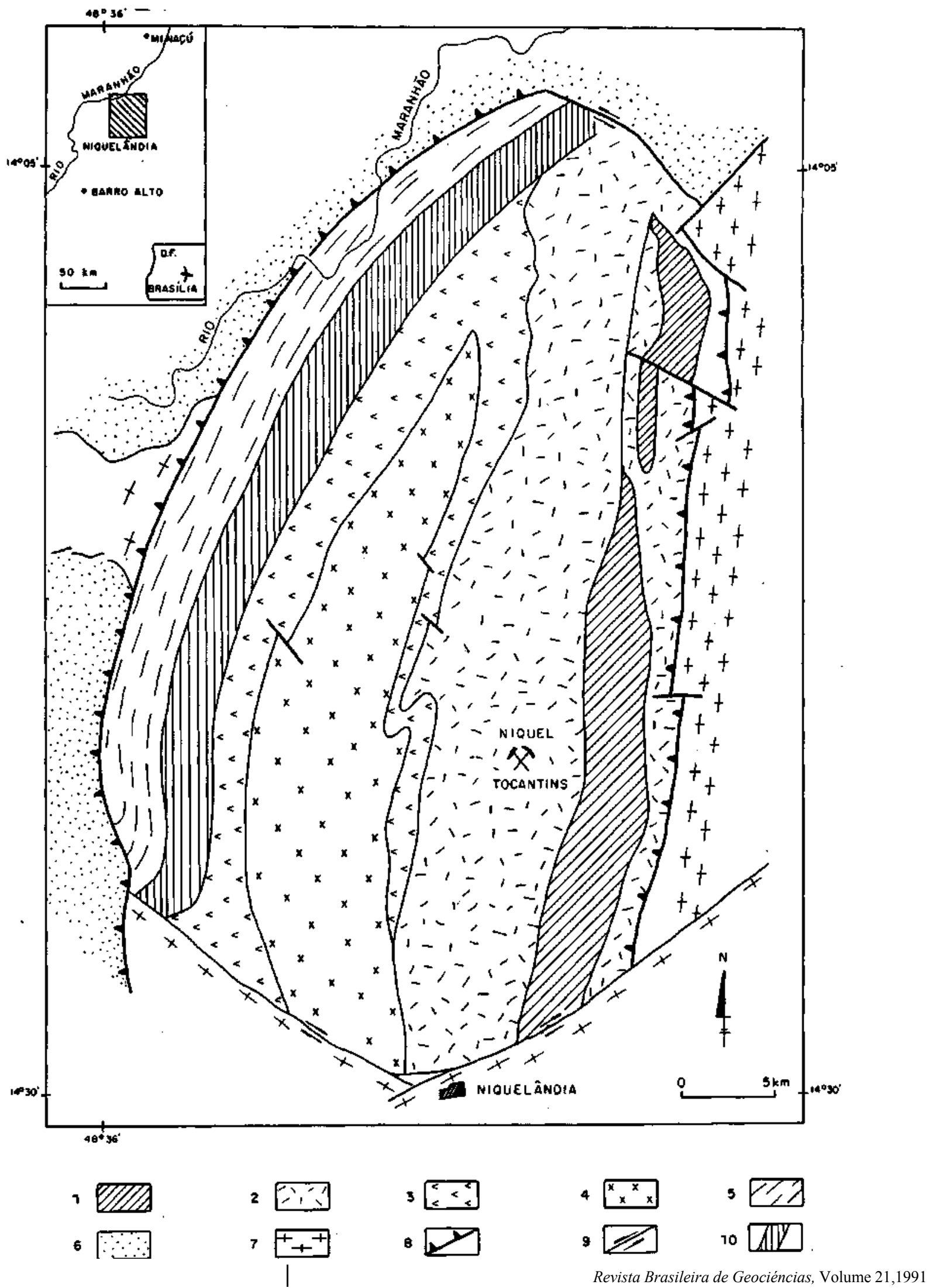

Figurall -Mapa geológico do Complexo de Niquelândia (GO), destacando a Zona de Cisalhamento do Rio Traíras (modificado de Brod 1988). 1. Metaperidotitos e metapiroxenitos; 2. granulitos noríticos e gabróicos; 3. anfibolitos finos; 4. anortositos do Complexo de Niquelândia; 5. Seqüência Vulcanossedimentar Coitezeiro - Indaianópolis; 6. Coberturas metassedimentares proterozóicas; 7. Zonas de Cisalhamento; 8. Falhas de Empurrão; 9. Movimento relativo de blocos como indicado; 10. Zona de Cisalhamento do Rio Traíras

Figure 1 - Geologic map of the Niquelândia Complex, Goiás, showing the Rio Traíras Shear Zone (modified after Brod 1988). 1. Metaperidotites and metapyroxenites; 2. noritic and gabbroic granulites; 3. fine-grained amphibolites; 4. anorthcdtes of the Niquelândia Complex; 5. Coitezeiro or Indaianópolis Volcano-sedimentary Sequence; 6. Proterozoic meta-sedimentary covers; 7. Shear zones; 8. Thrust Fauests; 9. relative displacement along faults; 10. Rio Traíras Shear Zone 
sotopostos aos sedimentos de fundo oceânico (Seqüência Coitezeiro), tendo na base uma transição de vulcânicas básicas para ácidas. Sob esta interpretação, o Complexo e a Seqüência Vulcanossedimentar estariam geotectônica e paleogeograficamente relacionados, o que não é necessariamente verdadeiro para uma interpretação do Complexo como um corpo estratiforme.

A Zona de Cisalhamento do Rio Traíras separa o Complexo de Niquelândia e a Seqüência Vulcanossedimentar Coitezeiro e é uma estrutura de ocorrência até então desconhecida como tal. As rochas pertencentes à zona de cisalhamento correspondem àquelas que, segundo a interpretação do Bloco de Niquelândia como restos de um ofiolito, estariam situadas na transição entre basaltos (anfibolitos finos) e a porção sedimentar da crosta oceânica, o que corresponderia à porção basal da Seqüência Coitezeiro (Indaianópolis). Não há referências sobre a posição que poderiam ocupar estas rochas segundo uma interpretação do Complexo como estratiforme.

ORIENTAÇÃO, ESTRUTURAS E DESLOCAMENTO DA ZONA DE CISALHAMENTO A Zona de Cisalhamento do Rio Traíras tem traçado geral variável (Fig. I). Do seu extremo norte até as proximidades da Fazenda Palmeira tem orientação N20-40E, com mergulho variando de $80^{\circ} \mathrm{SE}$ a vertical. Para sul, assume, ao longo de uma curvatura suave, direção N-S a N20W até a confluência dos Rios Criminoso e Traíras. Neste ponto, encurva-se para N70-60W ao longo de uma dobra de arrasto decorrente da zona de cisalhamento que marca o limite sul do Maciço de Niquelândia (Lineamento de Niquelândia, Brod 1988).

A estrutura planar mais proeminente é uma foliação milonítica de direção modal N20E a N40E, com mergulhos de $80^{\circ} \mathrm{SE}$ a $80^{\circ} \mathrm{NW}$ ÇFig. 2). As estruturas lineares estão contidas nos planos da foliação e compreendem eixos de dobras, $m u l$ lions, boudins e estíramento mineral. Com exceção do último, as lineações exibem caimentos variáveis de verticais a suborizontais para S10-24W (Fig. 2). Dobras de arrasto reclinadas e apertadas (Fig. 3), por vezes com flancos rompidos, megalitons dobrados de milonitos com porfiroblastos centimétricos de granada (Fig. 4), boudins dobrados e lentes de cisalhamento (Fig. 5) indicam que os movimentos ao longo da zona de cisalhamento foram policíclicos.

$\mathrm{Na}$ extremidade sul da zona de cisalhamento, suas estruturas estão dobradas e transpostas pelo Lineamento de Niquelândia (Fig. 1), o que impossibilita a sua utilização na interpretação cinemática. Para norte, as lineações de estiramento são suborizontais, paralelas à direção da foliação, sugerem um movimento transcorrente que, em conjunto com outros indicadores cinemáticos, tais como dobras da foliação milonítica e de diques de granito e sombras de pressão assimétricas, sugerem um sentido predominantemente dextrógiro. Uma componente vertical subordinada pode ser localmente indicada.

ROCHAS DA ZONA DE CISALHAMENTO As rochas da Zona de Cisalhamento do Rio Traíras pertencem ao grupo dos milonitos, em geral com recristalização suficiente para que sejam considerados como blastomilonitos. Quando considerados os protolitos, quatro subdomínios geográficos podem ser individualizados. No leste, os protolitos são anfibolitos da borda oeste do Maciço de Niquelândia. A porção centro-sul contém granites intrusivos sin a pós-cinemáticos. A porção centro-norte consiste de milonitos derivados ora de rochas da Seqüência Coitezeiro ora de rochas graníticas. Na porção oeste, os protolitos dominantes são rochas da Seqüência Coitezeiro.

Na porção leste, a zona de cisalhamento manifesta-se por uma foliação milonítica que cresce em intensidade para oeste,

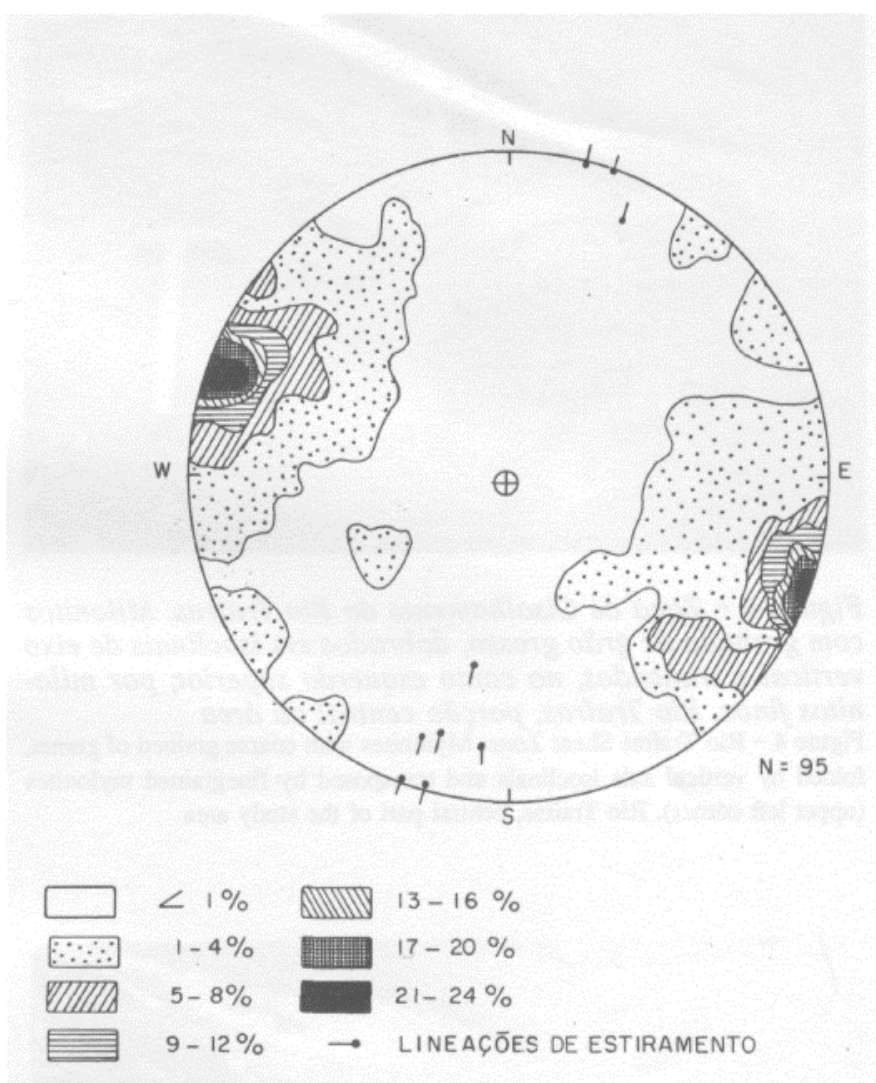

Figura 2 -Estereograma da foliação milonítica e lineações da Zona de Cisalhamento do Rio Traíras

Figure 2 - Stereographic plot of mylonitic foliation and lineations of the Rio Traíras Shear Zone

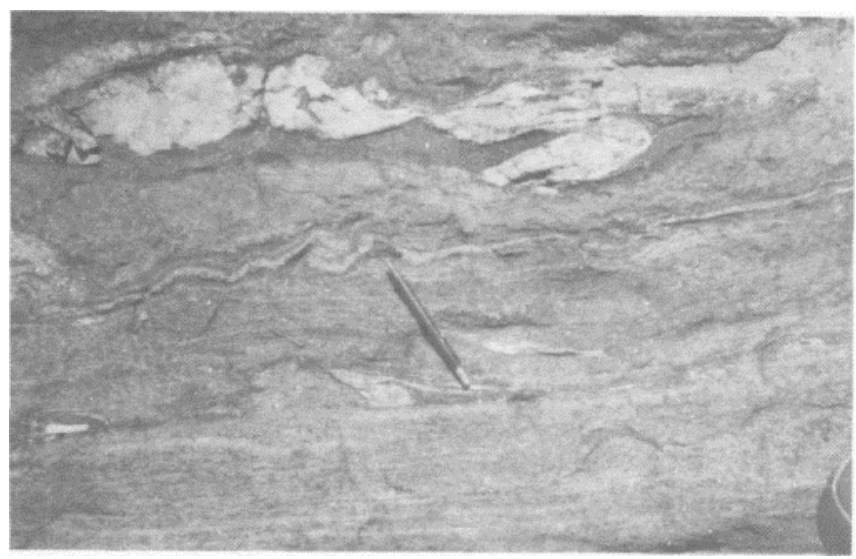

Figura 3 - Zona de Cisalhamento do Rio Traíras. Milonito de composição básica (anfibolito fino), mostrando veio de quartzo leitoso com dobras isoclinais de eixo vertical, rompidas por estreitas faixas de milonitos, bem como veio grynitico com dobras de arrasto desarmônicas, todos indicando movimento dextrógiro. Córrego Vai-Vem Figure 3 - Rio Traíras Shear Zone. Basic mylonite (fine-grained amphibolites), with quartz vein showing isoclinal folding. Folds are transposed by thin mylonitic bands. Granitic vein showing disharmonic drag folds. All structures denote dextral displacement. Córrego Vai-Vem

culminando em anfibolitos finos, mais facilmente reconhecíveis como milonitos quando os protolitos são de granulação grossa, ou onde o metamorfismo dinâmico propiciou reações 


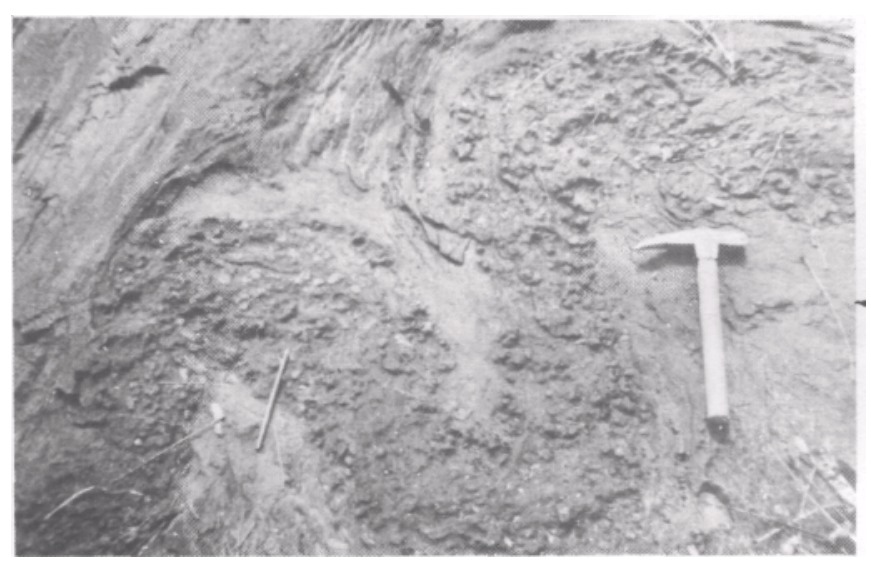

Figura 4 - Zona de Cisalhamento do Rio Trairas. Milonitos com granada de grão grosso, dobrados em isoclinais de eixo vertical e truncados, no canto esquerdo superior, por milonitos finos. Rio Traíras, porção central da área Figure 4 - Rio Traíras Shear Zone. Mylonites with coarse grained of garnet, folded by vertical axis isoclinais and transposed by finegrained mylonites (upper left comer). Rio Traíras, central part of the study area

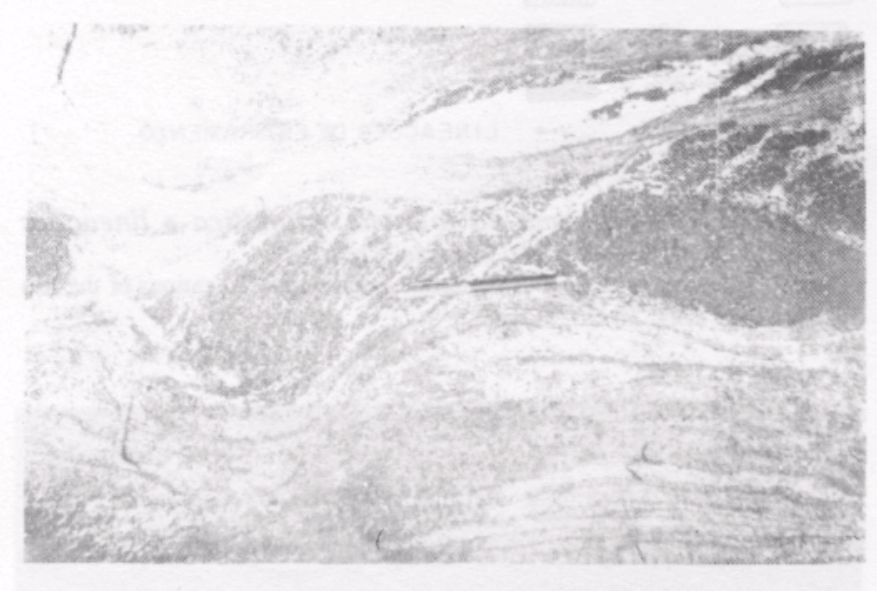

Figura 5 - Zona de Cisalhamento do Rio Traíras. Milonito sobre gabro-anortosito da borda oeste do Complexo de Niquelândia. Notar a diferença de granulação entre as lentes de cisalhamento e as faixas de milonito

Figure 5 - Rio Traíras Shear Zone. Mylonite after anorthositic gabbro of the western border of Niquelândia Complex. Note the difference in grain size from shear lenses to mylonitic bands

retrometamórficas. Quando os protolitos possuem granulação fina ou o metamorfismo dinâmico os homogeneizou textural e mineralogicamente, é difícil definir se a granulação fina é original ou resulta de deformação milonítica.

As rochas da faixa leste são protomilonitos, milonitos e ultramilonitos, com predominância dos dois últimos. Variações significativas na intensidade de deformação são visíveis da escala meso a microscópica. Os metabasitos milonitizados estão comumente injetados por diques félsicos, gradativamente mais escassos para leste.

Protomilonitos são melhor observados em gabros e anortositos grossos. Em lâmina delgada mostram porfiroclastos de andesina/labradorita, hornblenda, diopsídio, "hiperstênio" e granada em matriz milonítica fina e recristalizada. Porfiroclastos com granulação periférica, sombras de pressão, geminados e planos de cliragem deformados, extinção ondulante, filetes de milonitos e paragêneses neoformadas são feições características. Os milonitos (Fig. 6a) são predominantes e caracterizam-se por uma matriz recristalizada de granulação fina, por vezes bandada, com porfiroclastos de labradorita e diopsídio. A matriz excede $50 \%$ da rocha e consiste de um zoisita-anfibolito fino, verde escuro a preto, contendo hastingsita, zoisita, albita/oligoclásio, titanita, epídoto e quartzo.

Os ultramilonitos são anfibolitos de granulação muito fina, cuja natureza milonítica é mais facilmente reconhecível por suas relações com outros tipos texturais de rochas miloníticas. Em amostra de mão, são foliados, de cor verde-escuro a verde-acinzentado-escuro, com pontuações brancas de plagioclásio e manchas rosadas de granada. Fenoclastos milimétricos disseminados de plagioclásio são freqüentes. Bandamento é por vezes visível, pela alternância de níveis com maior ou menor abundância de anfibólio. Ao microscópio, mostram granulação fina a muito fina, textura orientada e estrutura por vezes bandada, na qual se alternam leitos com predominância ora de anfibólio ou piroxênio, ora de plagioclásio. Os constituintes minerais são hastingsita, andesina/labradorita, titanita, zircão, quartzo, opacos, granada e zoisita, localmente diopsídio e "hiperstênio".

Na porção centro-sul da zona de cisalhamento, predominam granitóides intrusivos, os quais correspondem aos "soda-anfibólio-gnaisses" (Danni \& Leonardos 1980), ou "anfibóliogranito-gnaisses" (Nascimento et al. 1981) da Associação Vulcânica Indaianópolis (Danni \& Leonardos 1980) e, em parte, aos granites intrusivos do tipo Morro Solto de Ribeiro \& Teixeira (1980).

Esta suíte contém charnockitos, egirina granitos, arfvedsonita granitos e granitos leucocráticos, milonitizados em maior ou menor escala. Brod (1988) propôs designá-la por Suíte Intrusiva Baunilha, com área-tipo na localidade homônima. Todos os granitóides da suíte estão confinados à zona de cisalhamento.

A porção centro-norte foi interpretada por Danni \& Leonardos (1980) e Nascimento et al. (1981) como constituída de meta-pelitos da Seqüência Indaianópolis e por Ribeiro Filho \& Teixeira (1980) como metas-sedimentos da Seqüência Palmeirópolis. Com efeito, os milonitos ali existentes derivam de metapelitos, porém relacionados à Seqüência Coitezeiro, localizada a oeste (Brod 1988). Milonitos derivados de injeções graníticas da Suíte Baunilha estão localmente presentes.

As rochas dessa faixa possuem cor cinza, granulação grossa, textura e foliação milonítica conspícuas e porfiroblastos rosados milimétricos a centimétricos de granada (ver Fig. 4). A mica predominante é ora muscovita ora biotita. Não raro, níveis sub-decimétricos de biotitito com porfiroblastos de granada altemam-se com faixas ricas em muscovita, conferindo à rocha um aspecto bandado. Ao microscópio apresentam textura milonítica grossa, comumente recortada por faixas de granulação mais fina. Os constituintes minerais são quartzo, oligoclásio, feldspato potássico, muscovita, biotita, turmalina, granada, estaurolita, sillimanita, epidoto, allanita, clinozoisita e apatita.

A zona oeste da zona de cisalhamento é uma faixa de milonitos derivados de diversos tipos de rochas da Seqüência Coitezeiro. Na porção norte, são comuns, em meio aos milonitos, lentes de quartzo leitoso, por vezes com cristais centimétricos a subdecimétricos deformados de muscovita e, localmente, cianita.

Em metapelitos, a zona de cisalhamento desenvolveu uma foliação milonítica anastomosada que contrasta com o caráter planar da foliação metamórfica. Nos protomilonitos e milonitos, os porfiroclastos mais comuns são restos de granada 

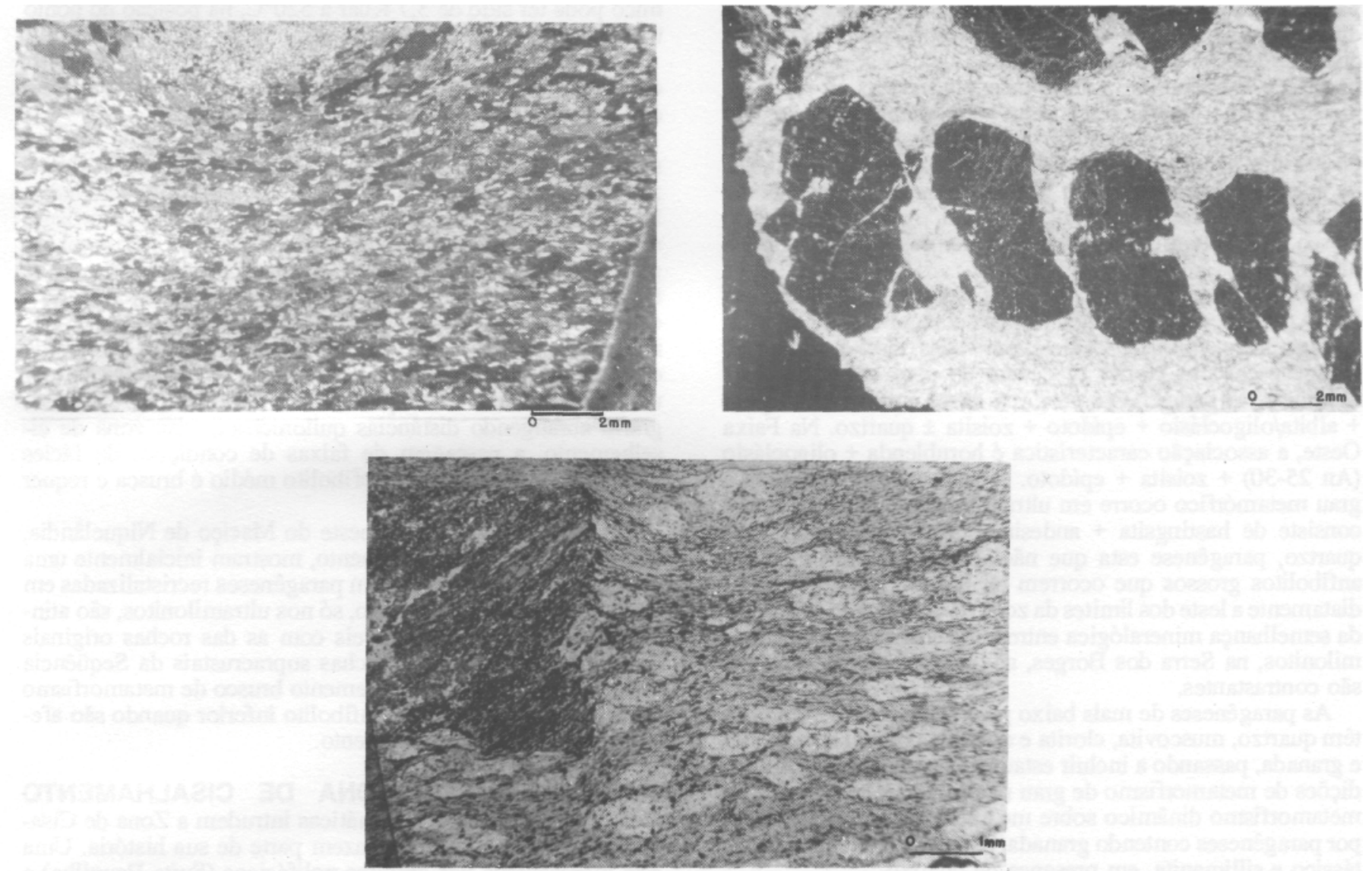

Figura 6 - Zona de Cisalhamento do Rio Traíras, a. Zona leste. Milonito de composição básica (anfibolito fino), com porfiroclastos centimétricos de piroxênio. b. Zona oeste. Fotomicrografia mostrando porfiroclasto de granada rompido e com sombra depressão emprotolito metapelítico da Seqüência Coitezeiro. Nicóis cruzados, c. Fotomicrografia de ultramilonito em metapelito da Seqüencia Coitezeiro, mostrando porfiroblasto de estaurolita e microlitons do xisto original em meio a uma matriz recristalizada. Luz natural

Figure 6 - Rio Traíras Shear Zone. a. Eastern zone. Basic mylonite (fine-grained amphibolites), with pyroxene porphyroclasts. b. Western zone. Photomicrograph showing a stretched garnet porphyroclast with pressure shadows, from Coitezeiro sequence metapelite. Crossed nicols. c. Fotomicrograph of ultramylonite from Coitezeiro sequence metapelite, showing staurolite porphyroblast and microlithons of original schists within a recrystallized matriz

(Fig. 6b), mais raramente muscovita e biotita. A matriz milonítica tem granulação fina e é rica em muscovita e clorita. Em direção a leste, estas rochas evoluem, por incremento na deformação, para milonitos e milonito-gnaisses porfiroblásticos da Zona Central Norte.

Os efeitos da milonitização sobre metassedimentos químicos resultaram na transformação dos metacherts em milonitos e ultramilonitos com intenso estiramento de quartzo, boudinagem dos leitos de opacos e desenvolvimento de uma forte textura ribbon.

Rochas metavulcânicas básicas resultam em protomilonitos a ultramilonitos. Nos primeiros, é característica a granulação periférica de cristais de plagioclásio e dos fragmentos líricos de metatufos. A progressão para milonitos ocorre por degradação de cristais de anfibólio, desenvolvimento de sombras de pressão e gradativo aumento das proporções de matriz, enquanto os antigos fenocristais de plagioclásio são transformados em lentes ou fitas de agregados poligonais finos. Nos ultramilonitos, a recristalização e transposição das texturas e estruturas vulcânicas originais é, em geral, completa.

Os efeitos da zona de cisalhamento sobre metavulcânicas ácidas estão melhor representados nos metatufos de cristal. Em escala mesoscópica, traduzem-se pelo estiramento de fenocristais de quartzo e feldspato potássico. Ao microscópio, as rochas variam de proto a ultramilonitos. Os fenocristais são transformados em porfiroclastos com extinção ondulante, granulação periférica e sombras de pressão, gradativamente incorporados á matriz milonítica. Nos metatufos, a foliação milonítica é definida por lamelas de biotita ou muscovita. Nas rochas com pouca ou nenhuma mica, a foliação é dada por forte estiramento do quartzo ou por alinhamento de opacos lamelares.

Rochas areno-pelíticas são transformadas em ultramilonitos. Em quartzitos, a deformação provocou forte extinção ondulante e estiramento do quartzo. Em sericita-magnetita xistos, desenvolveu-se uma foliação milonítica anastomosada, marcada pela orientação de opacos lamelares, palhetas submicroscópicas de sericita e raros grãos neoformados de quartzo. Imersos na matriz milonítica, ocorrem porfiroblastos de granada, estaurolita (Fig. 6b), cianita e microlithons dos xistos originais (Fig. 6c). Cloritóide xistos têm foliação milonítica definida por faixas de granulação fina, anastomosadas, constituídas por grãos estirados de quartzo, localmente recristalizados, além de opacos e muscovita orientados. O cloritóide é pré-cinemático a esta foliação.

METAMORFISMO DINÂMICO Grande parte das rochas da Zona de Cisalhamento do Rio Traíras possui composição química adequada para desenvolver paragêneses diagnosticas das condições de pressão e temperatura, se com- 
paradas com paragêneses clássicas do metamorfismo dinamotermal. Mesmo assim, o metamorfismo da zona de cisalhamento só pode ser investigado quanto ao espectro de pressão e temperatura, pois as diferentes zonas ou graus de metamorfismo dinâmico recortam-se mutuamente e são, não só diacrônicas, mas também policíclicas, não permitindo definir um padrão de variação espacial claro. As condições de metamorfismo dinâmico variam com a intensidade de cisalhamento e recristalização. Em geral, o grau metamórfico cresce dos protomilonítos para os milonitos e destes para os ultramilonitos.

As paragêneses minerais de mais baixo grau de metamorfismo dinâmico de protolitos básicos contêm actinolita, albita/oligoclásio, epídoto, zoisita e, por vezes, clorita, na qual as paragêneses com clorita precedem as com actinolita. Nos milonitos, as paragêneses da Zona Leste contêm hastingsita + albita/oligoclásio + epídoto + zoisita \pm quartzo. Na Faixa Oeste, a associação característica é hornblenda + oligoclásio (An 25-30) + zoisita + epídoto. A paragênese de mais alto grau metamórfico ocorre em ultramUonitos da Faixa Leste e consiste de hastingsita + andesina/labradorita + granada \pm quartzo, paragênese esta que não difere da encontrada em anfibolitos grossos que ocorrem na Serra dos Borges, imediatamente a leste dos limites da zona de cisalhamento. Apesar da semelhança mineralógica entre anfibolitos grossos e ultramilonitos, na Serra dos Borges, as diferenças de granulação são contrastantes.

As paragêneses de mais baixo grau sobre metapelitos contêm quartzo, muscovita, clorita e epídoto, com ou sem biotita e granada, passando a incluir estaurolita e/ou cianita sob condições de metamorfismo de grau médio. Ó limite superior do metamorfismo dinâmico sobre metapelitos está representado por paragêneses contendo granada, plagioclásio, feldspato potássico e sillimanita, em presença de quartzo.

As paragêneses de metamorfismo dinâmico sobre metapelitos são freqüentemente de granulação grossa (Fig. 4) e acompanham uma foliação milonítica anastomosada, o que contrasta com as paragêneses de metamorfismo regional, caracterizadas por uma granulação muito fina associada a uma foliação metamórfica regular. Ademais, nos metapelitos, as condições de metamorfismo não ultrapassam as da isógrada da biotita, em contraste com as de metamorfismo dinâmico que são, localmente, correspondentes à zona da granada, mas se estabilizam regionalmente a partir da zona da estaurolita.

Do exposto, conclui-se que o metamorfismo dinâmico da zona de cisalhamento cobre o intervalo de fácies xisto verde superior a anfíbolito (Fig. 7). As condições de pressão e temperatura mínimas, deduzidas a partir das paragêneses em metapelitos, podem estar representadas pela intersecção da curva de transformação de estilpnomelana em biotita com a da inversão de cianita em andalusita, o que corresponde, aproximadamente, a $3 \mathrm{kbar}$ a uma temperatura de $420^{\circ} \mathrm{C}$. A ausência de cordierita e andalusita, bem como a estabilização de sillimanita e estaurolita, indicam que, a cerca de $560^{\circ} \mathrm{C}$, a pressão mínima poderia ter continuado a $3 \mathrm{kbar}$, pela intersecção das curvas de reação estaurolita-cordierita e sillimanita-andalusita. A ausência de cordierita sugere que a pressão teria sido superior a 3,5 kbar a uma temperatura da ordem de $620^{\circ} \mathrm{C}$, como indica a intersecção da curva de transformação de muscovita em feldspato potássico com a da estabilização da cordierita. Entretanto, a ocorrência de cianita + granada implica em que a pressão pode ter atingido, localmente, um mínimo de $52 \mathrm{kbar}$ a cerca de $600^{\circ} \mathrm{C}$, se esta puder ser explicada por meio da instabilização da estaurolita, conforme mostra a intersecção da curva estaurolita-granada com a curva cianita-sillimanita.

Todas as intersecções justificariam, no intervalo de temperatura de $420^{\circ}$ a $560^{\circ} \mathrm{C}$, a aproximadamente $3 \mathrm{kbar}$, a estabilização da andalusita. Contudo, a ausência desse polimorfo indica que a pressão mínima durante o metamorfismo dinâ- mico pode ter sido de $3,7 \mathrm{Kbar}$ a $520^{\circ} \mathrm{C}$, na posição do ponto tríplice dos polimorfos aluminosos.

Tais condições não só explicam a ausência de andalusita, como são compatíveis com as diferentes paragêneses formadas em rochas de composição básica e pelítica.

Além dos aspectos comparativos entre a zona de cisalhamento e o Complexo de Niquelândia e a Seqüência Coitezeiro, algumas diferenças adicionais devem ser mencionadas. $\mathrm{Na}$ Seqüência Coitezeiro, as isógradas de metamorfismo regional estão dobradas e ajustadas ao padrão estrutural regional, o que contrasta com a zona de cisalhamento, onde fácies de alto e baixo grau podem coexistir lateralmente, confinadas a zonas estreitas de milonitos. Ademais, as zonas metamórficas observadas na Seqüência Coitezeiro e na borda oeste do Maciço de Niquelândia podem ser explicadas por uma relação linear entre pressão e temperatura, com zoneografia abrangendo distâncias quilométricas. Na zona de cisalhamento, a passagem de faixas de condições de fácies xisto verde para faixas de anfibolito médio é brusca e requer poucos metros.

Os anfibolitos da borda oeste do Maciço de Niquelândia, quando afetados pelo lineamento, mostram inicialmente uma queda no metamorfismo, com paragêneses recristalizadas em fácies xisto verde. Neste caso, só nos ultramilonitos, são atingidas paragêneses compatíveis com as das rochas originais da Serra dos Borges. As rochas supracrustais da Seqüência Coitezeiro mostram um incremento brusco de metamorfismo de fácies xisto verde para anfibolito inferior quando são afetadas pela zona de cisalhamento.

\section{MAGMATISMO NA ZONA DE CISALHAMENTO}

Duas suites sin a tardi-cinemáticas intrudem a Zona de Cisalhamento do Rio Traíras e fazem parte de sua história. Uma está representada por granitos poltfásicos (Suíte Baunilha) e a outra por diques de composição básica (Suíte Fazenda São João). Ambas mostram evidências de intrusões recíprocas, e variam desde indeformadas até completamente milonitizadas.

Suite Granitica Baunilha A Suíte Baunilha aflora em uma faixa com largura aproximada de $2 \mathrm{~km}$, na porção centro sul da zona de cisalhamento. Consiste de uma série de intrusões de dimensão e composição variadas, em geral tabulares, alojadas segundo a foliação milonítica. Pequenos corpos circulares são delineáveis em imagem de radar.

Diques graníticos centimétricos a métricos permeiam a foliação milonítica, em especial nas bordas leste e oeste da zona de cisalhamento. Em geral, são paralelos à foliação, mas diques discordantes ou em stockwork não são raros.

Xenólitos centimétricos a métricos de milonito estão presentes. Possuem contornos arredondados, ovalados, em meia lua ou retangulares quando pouco deformados, passando a achatados ou fitas onde a deformação milonítica é intensa. Sua abundância sugere um mecanismo preferencial de intrusão por magmatic stopping. Os efeitos térmicos nas encaixantes e nos xenólitos manifestam-se por recristalização, silicificação e, localmente, por cornubianitos afaníticos, bandados, por vezes com textura maculosa.

Mesoscopicamente, os granitóides da Suíte Baunilha possuem cor cinza-claro a escuro nos diferenciados iniciais, passando a branco ou rosa nos termos mais silicosos. São, em geral, sacaróides, com raros termos porfiríticos. Ao microscópio, a textura é eqüigranular fina, hipidiomórfica a xenomórfica, freqüentemente poiquilítica, localmente porfirítica.

Deformação milonítica de intensidade variável superimpõe-se às texturas magmáticas, gerando proto a ultramilonitos com extinção ondulante, estiramento, granulação periférica, deformação de geminados, recristalização e orientação generalizada dos constituintes minerais. Faixas miloníticas são freqüentes e resultam da redução da granulação e neoformação 


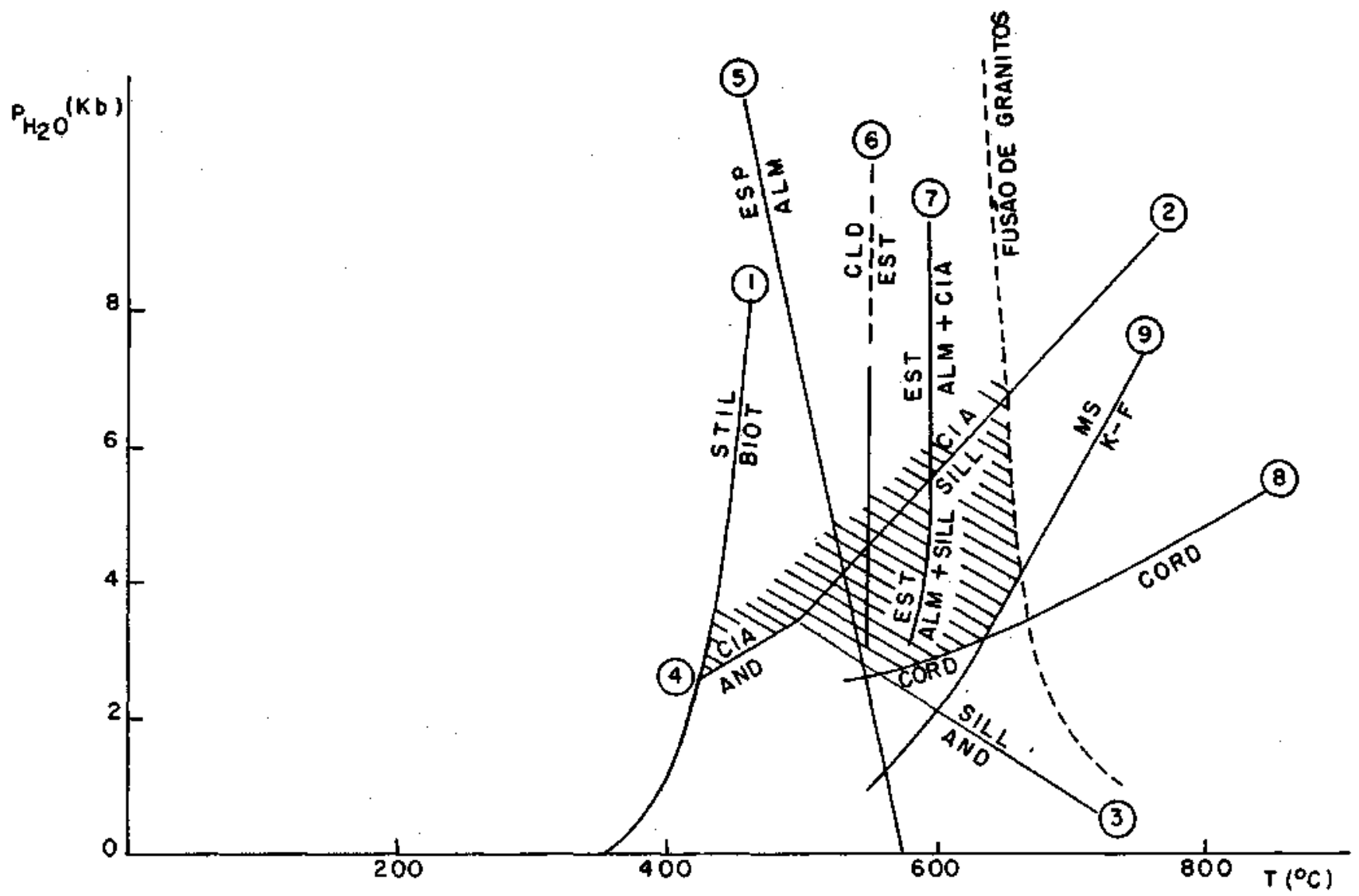

Figura 7 - Intervalo de estabilidade das paragêneses minerais observadas nos milonitos da Zona de Cisalhamento do Rio Traíras. O limite superior da estabilidade depirofilita e aluminossilicatos está representado segundo Newton (1966), Richardson et al. (1969) e Holdaway (1971). A curva de fusão mínima do sistema granítico, segundo Luth et al. (1964). A reação clorita + musco vita + quartzo estaurolita ou cordierita, dependendo da pressão, segundo Seifert (1970) e Bird \& Fawcett (1973). O limite inferior da estabilidade da álmandina está representado segundo Hsu (1968). Relações de estabilidade entre cloritóide, cordierita e estaurolita são de Ganguly (1969,1972), Richardson (1968) e Hoscheck (1969). Curva de conversão de stilpnomelana em biotita, conforme proposto por Winkler (1976)

Hgure 7 - Stability relations of the paragenesis observed in tbe Rio Traíras Shear Zone. Upper stability limit of pyrophyllite and Al-silicates according to Newton (1966), Richardson et al. (1969) and Holdaway (1971). Curve of minimum melt of granite according to Luth et al. (1964). CMorite+muscovite+quartz $=$ staurolite or cordierite, depending on pressure from Seifert (1970) and Bird \& Fawcett (1973). Lower stability limit of almandine from Hsu (1968). Stability relationships between chloritoid, cordierite and staurolite according to Ganguly $(1969,1972)$, Richardson (1968) and Hoscheck (1969). Curve of stilpnomelane-biotite conversion as proposed by Winkler (1976)

de quartzo, albita e biotita. Os porfiroclastos são de feldspato potássico e plagioclásio.

Texturas resultantes de autometassomatismo por NaiO, $\mathrm{K}_{2} \mathrm{O}, \mathrm{SiO}_{2}$ e boro são abundantes e obliteram muitas das texturas magmáticas originais e das feições miloníticas. Alterações deutéricas, como sericitização e propüitização, são raras.

As proporções entre minerais essenciais e acessórios permitem dividir os granitóides da Suite Baunilha em quatro grupos: chamockitos, egirina-biotita granitóides, anfibólio granitóides e granitóides leucocráticos. Embora possuam propriedades mineralógicas e composicionais diferentes, suas relações espaciais e temporais estão, em geral, obliteradas por deformação e são ainda desconhecidas.

Os chamockitos consistem de quartzo, plagioclásio (oligoclásio/andesina e albita) e feldspato potássico, com "hiperstênio" varietal. Os acessórios são allanita, titanita, magnetita e ilmenita, com apatita, zircão e biotita subordinados. Albita, microclinio e dumortierita são fases metassomáticas. Epídoto, clinozoisita, "leucoxênio" e sericita são produtos de alteração.

Os egirina-biotita granitóides variam de sienitos a álcaligranitos. Os constituintes essenciais são quartzo, plagioclásio (oligoclásio/andesina e albita) e feldspato potássico, com bio- tita, titanita, apatita, opacos, epídoto e allanita como acessórios. Egirina, albita, microclinio e dumortierita são metassomáticos. "Leucoxênio", clinozoisita e raras clorita e sericita são produtos de alteração secundária.

Os anfibólio granitóides variam de dioritos a granites. Os minerais essenciais são quartzo, plagioclásio (oligoclásio/andesina e albita) e, subordinadamente, feldspato potássico. Biotita, titanita, opacos, apatita, allanita e raro zircão são acessórios. Arfvedsonita, epídoto, clinozoisita, albita e microclinio são metassomáticos. "Leucoxênio", clinozoisita e raro carbonato são secundários.

Os granitos leucocráticos são rochas com tendência alasquítica e possuem ocorrência restrita. Seus constituintes essenciais compreendem quartzo, oligpclásio, albita e, subordinadamente, feldspato potássico. Titanita e allanita são acessórios e biotita, muscovita, actinolita e granada são subacessórios. Albita é metassomática e epídoto é produto de transformação da allanita.

A interpretação petroquímica dos granitóides da Suíte Baunilha deve considerar que parte de suas características químicas resulta de autometassomatismo, com acréscimo de sílica, álcalis e boro. Das relações texturais entre seus minerais con- 
clui-se que quartzo, plagioclásio (andesina ou oligoclásio), feldspato potássico (ortoclásio ou microclínio), biotita, actinolita, "hiperstênio", titanita, magnetíta, ilmenita, apatita, epídoto e allanita são minerais magmáticos. Produtos metassomáticos estão representados por albita, microclínio, egirina, arfvedsonita e dumortierita.

A composição normativa CIPWdos granitóides varia entre os diferentes grupos. Os charnockitos possuem abundante egirina normativa, predomínio de ortoclásio sobre albita e, por vezes, diopsidio e wollastonita em lugar de "hiperstênio". Os egirina-biotita granitóides caracterizam-se por ser, em parte, egirina normativos. Sua razão Ab/Or é a mais baixa observada dentre os granitóides da suíte, variando de 1,1 a 1,5. Quando presente, o "hiperstênio" normativo é mais rico na molécula de ferrossilita. Os anfibólio granitóides possuem norma com "hiperstênio" rico na molécula de ferrossilita. A razão $\mathrm{Ab} / \mathrm{Or}$ é superior a 1 e pode alcançar valores extremamente altos, provavelmente associados a sítios de metassomatismo sódico mais intenso. Os granitos leucocráticos são coríndon normativos, o que está de acordo com a presença de granada e muscovita. Em geral, possuem razão Ab/Or superior álea enstatita é a molécula dominante no "hiperstênio". A presença de anortita é mais expressiva à medida que aumentam as proporções de $\mathrm{SiO}_{2}$.

No diagrama da figura $8 \mathrm{a}$, os charnockitos são localizados como granitos e álcali-granitos. Os granitos leucocráticos com $\mathrm{Na}_{2} \mathrm{O}$ e $\mathrm{FeO} / \mathrm{Fe}_{2} \mathrm{O}_{3}$ normais caíram nos campos do tonalito e do granito, ao passo que aqueles com altas proporções de $\mathrm{Na}_{2} \mathrm{O}$ são álcali-granitos e granitos. Os anfibólio granitóides são tonalitos, quartzo monzonitos, sienogranitos, álcali-granitos, quartzo sienitos e sienitos. Os egirina-biotita granitóides localizaram-se nos campos do sienogranito, álcali-granito e sienito, e são as rochas de tendência mais alcalina da suíte.

A aparente diversidade composicional destes granitóides no diagrama da figura 9a decorre de dois conjuntos de rochas com trends diferentes, evidenciados na figura $8 \mathrm{~b}$. O primeiro reúne granitóides leucocráticos e anfibólio granitóides ao longo de um trend com proporções maiores de $\mathrm{MgO}$ que o segundo, onde se situam os demais.

Para vários óxidos, é possível identificar substanciais diferenças entre os granitóides da Suíte Baunilha (Tab. 1). Os granitóides leucocráticos possuem proporções altas de $\mathrm{TiO}_{2}$, $\mathrm{Al}_{2} \mathrm{O}_{3}, \mathrm{CaO}$ e $\mathrm{P}_{2} \mathrm{O}_{5}$, intermediárias de $\mathrm{Na}_{2} \mathrm{O}, \mathrm{MnO}$ e $\mathrm{K}_{2} \mathrm{O}$ e bastante variáveis de $\mathrm{Fe}$ total. Os anfibólio granitóides possuem baixo $\mathrm{Fe}$ total e $\mathrm{TiO}_{2}$, proporções ligeiramente elevadas de $\mathrm{MgO}$ e intermediárias de $\mathrm{Al}_{2} \mathrm{O}_{3}, \mathrm{CaO}, \mathrm{MnO}$ e $\mathrm{Na}_{2} \mathrm{O}$. Os egirina-biotita granitos tem baixo $\mathrm{TiO}_{2}, \mathrm{Al}_{2} \mathrm{O}_{3}, \mathrm{CaO}$ e $\mathrm{MgO}$, mas alto Fe total e MnO. Tanto os anfibólio granitóides quanto os egirina-biotita granitóides têm $\mathrm{K}_{2} \mathrm{O}$ mais alto que os granitos leucocráticos, mas enquanto nos anfibólio granitóides o $\mathrm{K}_{2} \mathrm{O}$ é alto para os teores intermediários de $\mathrm{SiO}_{2}$, nos egirina-biotita granitóides é baixo.

Enquanto na figura $8 \mathrm{a}$ as rochas da Suíte Baunilha se distribuem em dois grupos, na figura 8c, discriminam-se nitidamente três. Os granitóides leucocráticos têm uma tendência intermediária entre suites cálcicas e cálcio-alcalinas, os anfibólio granitóides mostram tendência entre cálcio-alcalina e álcali-cálcica e os egirina-biotita granitóides têm tendência alcalina. Estas observações são corroboradas pela dispersão obtida no diagrama da figura $8 \mathrm{~d}$. Os granitóides leucocráticos localizam-se ora no campo cálcio-alcalino, ora no das rochas alcalinas, os anfibólio granitóides no dos granitos alcalinos mas com baixo índice de alcalinidade e os egirina-biotita granitóides ocupam ora o dos granitos alcalinos com alto índice de alcalinidade, ora o dos granitos peralcalinos. No diagrama da figura 8e, observa-se um comportamento semelhante, onde os granitos leucocráticos loca- lizam-se no campodas suites ora cálcio-alcalinas ora alcalinas, os anfibólio granitóides caem no limite entre suites alcalinas e calco-alcalinas e os egirina-biotita granitos no campo das suítes alcalinas. O mesmo é observado no diagrama da figura $8 \mathrm{f}$, mas várias amostras com tendência alcalina nos diagramas precedentes localizam-se fora do campo dos granitos alcalinos, devido a estreita variação nos teores de $\mathrm{MgO}$.

Uma tentativa para discriminar ambientes geotectônicos, aos quais as rochas estudadas poderiam estar relacionadas, mostra (Fig. 9) que os granitos leucocráticos situam-se no campo dos granitos pré-colisionais e no de granitos tardiorogênicos a anorogênicos. Os anfibólio granitos e os egirina-biotita granitos situam-se, respectivamente, no campo dos granitos tardi-orogênicos e anorogênicos. Pela figura $9 b$, a maioria das amostras tem afinidade com granitos intraplaca ou com granitos de cadeia oceânica (exceto os do tipo forearc basin). Nas figuras 9c e 9d, situam-se no campo dos granitos intraplaca ou dos granitos de segmentos anômalos de cadeias oceânicas.

A composição dos diferentes grupos de granitóides da Suíte Baunilha sugere que estes não são produtos de diferenciação. A deformação milonítica é menos intensa à medida que a alcalinidade cresce, o que sugere que o grupo de tendência mais alcalina (egirina-biotita granitóides) é também o mais jovem na evolução da zona de cisalhamento. Por outro lado, a formação da arfvedsonita por metassomatismo de granitos leucocráticos sugere que os anfibólio granitóides podem ser derivados dos primeiros. Neste caso, a introdução de álcalis poderia explicar o seu comportamento transicional entre os granitóides leucocráticos e os egirina-biotita granitóides.

Suíte Básica Fazenda São João A Suíte Fazenda São João é um conjunto de intrusões tubulares que ocorrem no interior do Lineamento Rio Traíras. As intrusões são concordantes com a foliação milonítica e possuem espessura métrica a subectamétrica; os comprimentos são hectamétricos a quilométricos. As intrusões variam desde indeformadas até completamente milonitizadas, as mais comuns. A variação de estilos e estados de deformação sugere que a Suíte São João implantou-se durante um longo período de tempo da evolução da zona de cisalhamento.

A intrusão-tipo, situada na Fazenda São João, é um corpo pouco deformado com cerca de $300 \mathrm{~m}$ de espessura e $9 \mathrm{~km}$ de comprimento, caracterizado por bandas e massas de prismas euédricos centimétricos de hornblenda em matriz de homblenda e raro plagioclásio fino. Estas bandas alternam-se com massas de hornblenda gabro de granulação fina, localmente com fenocristais de anfibólio. Acamamento magmático, dado por cumulados de hornblenda grossa, é freqüente.

Autólitos, xenólitos e cavidades miarolíticas são abundantes. Os autólitos consistem de microgabros e hornblenditos porfiriticos de granulação muito fina. Os xenólitos consistem de metabasaltos milonitizados, com foliação proeminente. Cavidades miarolíticas são freqüentes e atingem até 10 a $15 \mathrm{~cm}$ de diâmetro, possuem contornos irregulares, formas ovaladas ou esféricas e são atapetadas por prismas euédricos de anfibólio.

As feições mesoscópicas são destruídas à proporção que os efeitos do cisalhamento são mais pronunciados. Os grandes cristais de hornblenda sofrem redução de tamanho por granulação periférica e forma-se matriz milonítica foliada, semelhante a anfibolito de granulação fina. No interior da faixa de granitos da Suíte Baunilha, as intrusões básicas milonitizadas são facilmente confundidas com restos de anfibolitos da borda oeste do Maciço de Niquelândia

Mesoscopicamente, as rochas da Suíte Fazenda São João 

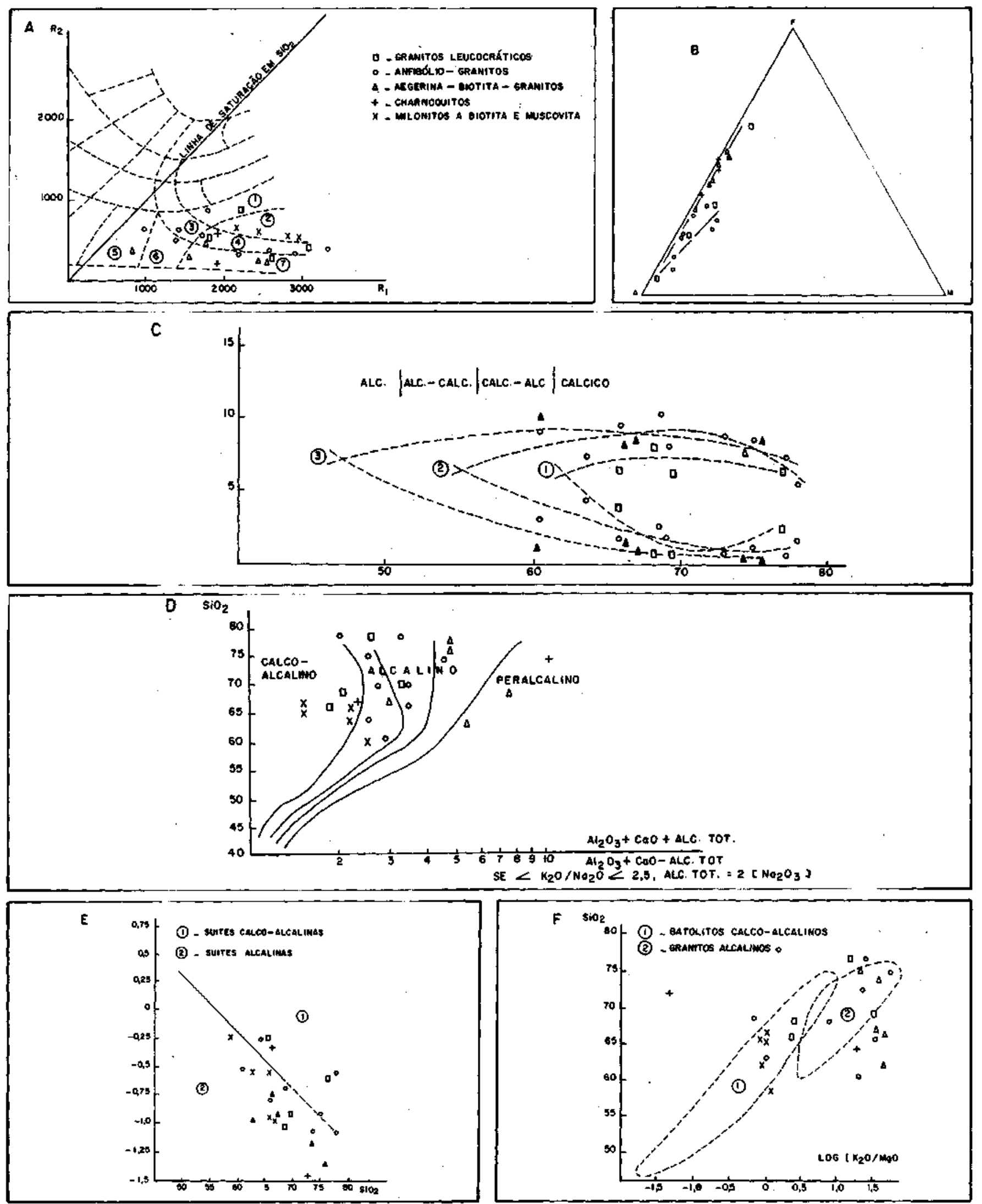

Figura 8 - Suite Baunilha, a. Diagrama R1-R2 (De la Roche et al 1980) para as rochas da Suite Baunilha, mostrando as seguintes divisões petrográficas: 1. tonalito, 2. granodorito, 3. quartzo-monzonito, 4. granito, 5. sienito, 6. quartzo sienito, 7. álcali-granito. b. Diagrama AFM dos granitóides da Suite Baunilha, mostrando pelo menos duas associações de rochas diferentes, c. Diagrama de Peacock (1931). d. Diagrama de Wright (1969). e. Diagrama de Brown (1981). f. Diagrama de Rogers \& Greenberg (1981)

Figure 8 - Baunilha Suite, a. R1-R2-Diagram (De la Roche 1980) showing the following fields: 1. tonalite, 2. granodiorite, 3. quattz-monzonite, 4. granite, 5. syenite, 6. quartz-syenite, 7. alkali-granite, b. AFM-Diagtam showing at least two different groups of rocks, c, d, e, and f diagrams respectively from Peacock (1931), Wright (1969), Brown (1981) and Rogers \& Greenberg (1981) 
Tabela 1 - Suite Baunilha - óxidos de elementos maiores (\% em peso), elementos menores (ppm) e norma CIPW (\% em peso), CH: charnoquito; ABG: egirina-biotita granitoide; $\boldsymbol{A G}$ : anfibólito-granitóide; GL: granitoide leucocratico; MIL: milonito..

\begin{tabular}{|c|c|c|c|c|c|c|c|c|c|c|c|c|c|c|c|c|c|c|c|c|c|c|c|}
\hline $\mathrm{Mgerma}$ & $\overline{1}$ & $\overrightarrow{2}$ & ${ }_{3}$ & $\stackrel{4}{4}$ & $\begin{array}{c}\mathrm{ABC} \\
5\end{array}$ & $\begin{array}{c}A B O \\
6\end{array}$ & ABO & $\begin{array}{c}40 \\
8\end{array}$ & $\begin{array}{c}\mathbf{A O} \\
9\end{array}$ & 10 & Ad & $\begin{array}{l}\mathrm{AO} \\
12\end{array}$ & $\begin{array}{c}109 \\
13\end{array}$ & $\begin{array}{c}10 \\
14\end{array}$ & Ad & 10 & $\begin{array}{l}10 \\
17\end{array}$ & At & 19 & $\begin{array}{l}10 \\
20\end{array}$ & 21 & $\frac{\text { MIII }}{22}$ & 23 \\
\hline \$o. & 65,50 & 72,50 & 62,38 & 66,26 & 67,03 & 74,26 & 75,48 & 0,34 & 6136 & 6,27 & 6,50 & $\operatorname{tax}$ & 72,82 & $74 \$ 1$ & 77,15 & $n, p$ & 65,80 & 601 & 0,34 & 36,94 & 53,20 & 62:58 & 66,19 \\
\hline $\mathrm{MO}_{2}$ & 0,7 & Q.41 & 1,26 & 0,77 & 0,4 & 0,40 & 0,33 & 0,57 & 983 & 0,45 & 0,59 & 0,30 & 0,28 & a.2s & 0,13 & 0,14 & 1,05 & 963 & Q.44 & 0,83 & 1,87 & $Q, 28$ & 0,71 \\
\hline $\mathrm{Al}=\mathrm{O}$ & 14,94 & 10,64 & 13,50 & 13.08 & 10,13 & 10,97 & 11,17 & 15,04 & 12,16 & 25,54 & 15,96 & 15,25 & 11,95 & 11,16 & 12,7 & 02,33 & 16,99 & 2090 & 2,51 & 11,95 & $12,5 t$ & 14,26 & 15,71 \\
\hline FeO, & $\sin$ & 5,23 & 6,00 & 4,95 & 25 & 474 & 3,21 & 500 & 2,00 & 3,06 & 1,15 & 0,10 & 1,13 & a2t & Q,ss & 101 & 3,35 & 9,33 & 11,54 & 0,97 & 5,08 & 3,86 & 3,39 \\
\hline$P=0$ & 1,13 & 2,12 & 4,0 & 4,42 & 2,4 & 1,00 & 0,84 & 5,00 & 422 & 2,46 & 0,10 & $\mathbf{3 , 1 2}$ & 2,91 & 1,26 & 0,0 & 0,68 & 0,58 & 0,34 & Q99 & 090 & 6,16 & 4,86 & 3,86 \\
\hline$c 0$ & 244 & 0,34 & 1,12 & 1,53 & 1,0: & $a 4$ & 0,41 & 2,91 & 435 & 1,71 & 262 & 1,65 & 0,76 & jot & $a s$ & 100 & $3,7 \mathrm{~s}$ & 0,73 & $a \times 0$ & 1,57 & 4,34 & 166 & 0,60 \\
\hline MpO & Q.10 & 0,18 & 0,10 & 0,10 & 0,10 & Q.10 & 0,20 & 0,19 & $2 \pi$ & 0,12 & 0,64 & 0,8 & 0.19 & a.10 & a.10 & 0,10 & 0.99 & 0,10 & a.10 & 0.10 & 1,00 & 347 & 3,43 \\
\hline$M$ & Q,15 & Q.11 & $a, 24$ & 0,26 & $a, n$ & Q10 & 0,07 & 0,28 & 0,11 & 0,14 & 0,10 & 0,10 & 0,10 & 0,10 & Q.20 & 0,10 & 0,10 & 010 & $a \times 3$ & 0,10 & 0.25 & $a_{17}$ & 0,10 \\
\hline $\mathbf{N}=0$ & 5,15 & 477 & 5,00 & 3,02 & 5,00 & 3,00 & 3,26 & 5,00 & 4,47 & 5,000 & 5,00 & 700 & 426 & 2,83 & 473 & 5,00 & 4,00 & 7,62 & 2,00 & 168 & 400 & 3,18 & 1,96 \\
\hline $\mathbf{x}_{9} 0$ & 2,00 & 4,56 & 4,85 & 4,31 & 3,16 & $\mathbf{3 , 5 1}$ & 465 & 3,92 & 29 & 4,45 & 5,00 & 0,45 & 4,47 & 5,05 & 2,45 & 0,16 & 1,84 & 026 & 3,3 & 1,57 & 268 & 3,00 & 305 \\
\hline no, & 9.17 & 0,02 & 0,10 & 0,10 & 0,10 & 0,10 & 0,01 & 0,12 & 0,12 & 0,10 & 0,10 & 036 & end & 0,10 & 0,10 & 0,10 & 0,35 & 0,10 & Q.10 & 0,10 & 0,70 & 0.22 & 0,10 \\
\hline PR. & 9,30 & 0,36 & 0,10 & 0,10 & 0,30 & 0,15 & 0,36 & 0,20 & 0,50 & 025 & 0,25 & 0,95 & 0,33 & 0.15 & $0 \times 0$ & 0,00 & 0,50 & oss & Q35 & Q,4s & 0,45 & alo & 1,55 \\
\hline Tonil & 99,37 & $100, n$ & 90,99 & 9,70 & $99, \pi 0$ & $\operatorname{san}$ & 100,62 & 9927 & $\sin$ & 9925 & soops & pas & 924 & 9423 & $\sin 66$ & $9, x$ & 9,70 & 9963 & 99,4 & 100,16 & 9,02 & 99,22 & 100,65 \\
\hline C. & is & 5 & 5 & 10 & 10 & $\mathbf{s}$ & 5 & 25 & 25 & $s$ & s & \$0 & 10 & 10 & 4 & 2 & s & 5 & s & 45 & 3 & 5 & 5 \\
\hline 20 & 8 & 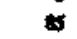 & 105 & 160 & 115 & 320 & 95 & 105 & 6 & 55 & 10 & 4 & 50 & 35 & $\mathbf{2 0}$ & 10 & 40 & 5 & 305 & ss & 215 & 100 & 30 \\
\hline$M$ & 5 & 5 & 5 & 3 & 5 & 5 & 5 & 5 & 30 & 5 & 5 & 5 & 5 & 5 & 5 & 5 & 5 & 5 & 10 & 5 & 5 & 55 & 40 \\
\hline L & $\pi$ & 150 & 30 & 70 & 30 & 100 & $\mathbf{L S O}$ & 150 & 150 & 200 & 150 & 100 & 50 & 200 & $\pi$ & 30 & 90 & 50 & 70 & 300 & 250 & 30 & 30 \\
\hline$z$ & 200 & 200 & 50 & 100 & $\pi$ & 200 & 150 & to & 70 & 150 & 100 & 150 & 300 & 1000 & 70 & 130 & 150 & 150 & 30 & 500 & 500 & 100 & 50 \\
\hline $\mathrm{m}$ & 0 & 30 & 10 & 30 & $\boldsymbol{x}$ & 3 & 30 & 20 & so & 30 & 20 & 20 & so & so & 10 & $\mathbf{0}$ & 30 & 10 & 30 & 30 & $n$ & 10 & 10 \\
\hline $\mathbf{Y}$ & $n$ & 30 & 30 & 50 & $\mathbf{3 0}$ & 100 & 30 & 50 & 150 & 100 & 70 & 30 & 100 & 150 & $\pi$ & 150 & 70 & $n$ & 30 & 150 & 250 & 30 & Is \\
\hline E & 1000 & 20 & 150 & 500 & $x$ & $\pi$ & $x$ & 500 & $\pi$ & 150 & 3000 & 300 & $m$ & $\pi$ & 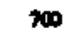 & $\pi$ & 100 & 30 & 70 & 70 & 300 & 300 & 700 \\
\hline 5 & 200 & 100 & 100 & 100 & 100 & 100 & 100 & 100 & 150 & 100 & 100 & 150 & 100 & 100 & 100 & 500 & 100 & 100 & 100 & 150 & 150 & 200 & 100 \\
\hline $\mathbf{v}$ & $\boldsymbol{x}$ & 10 & 10 & 10 & 15 & 15 & 10 & 15 & 200 & 15 & 15 & is & 10 & 15 & 15 & 20 & 15 & 20 & 15 & Is & 50 & 100 & 50 \\
\hline 0 & 23,6 & 29,43 & 11,0 & 23,56 & 25,34 & 36,18 & 34,59 & 9,34 & 14,18 & 15,40 & 13,07 & 16,0 & 20,26 & 34, & 3476 & 4,20 & 23,96 & 21,52 & 39,60 & 40,63 & 10,36 & 2.61 & 35,82 \\
\hline ch & $11,9 \mathrm{~s}$ & 26,99 & 20, & 2557 & 21,91 & 22,3 & 2751 & 23,38 & 17,57 & 26,56 & 20,12 & $2 \pi 7$ & 25,70 & 3369 & 14,56 & 0,95 & 10,96 & 1,55 & 19,38 & 900 & 16,06 & 1861 & 18,19 \\
\hline $\mathbf{A B}$ & 43,8 & 29,39 & 42,24 & 32,45 & $31, \%$ & 33.02 & 31,32 & 4,53 & 38,51 & 00,59 & 45,50 & sen & $36, M$ & 24,17 & 40,41 & 4,23 & 30,23 & 65,07 & 23,91 & 3971 & 42,05 & 27,34 & 16.73 \\
\hline $\mathbf{A N}$ & 21,10 & & & $5, \mu$ & & 1,18 & & 6,63 & 4,57 & 6,43 & 452 & $\operatorname{sen}$ & 0.25 & 2,45 & 2,0 & 613 & 16,45 & 300 & 2,44 & 690 & 4,28 & 691 & 2,34 \\
\hline$A C$ & & 9,43 & 2,14 & & 9,0 & & 1,11 & & & & & & & & & & & & & & & & \\
\hline 90 & & & & & & & & & & & 1,41 & & & & & & & & & & & & \\
\hline D & & 0,97 & 4,33 & 0,9 & a,s4 & 0,54 & 1,07 & 6,26 & 13,52 & 128 & 3,42 & & 206 & 1,99 & & & & & & Q14 & 10,68 & & \\
\hline c & 0,28 & & & & & & & & & & & $0, \infty$ & & & 1,44 & 1,12 & 1,46 & 696 & 936 & & & 3,23 & 800 \\
\hline HY & 0,25 & & acs & 298 & & & & 1, 1 & 5,23 & 1,16 & & 7,51 & 3,16 & a & 1 & 0 & 19 & 0.25 & 0,25 & Q.19 & 3,31 & 13,58 & 11,95 \\
\hline EN & 0,25 & & got & 0,21 & & & & 0,12 & 3,23 & 0,19 & & 2,2 & 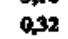 & a) & $a$ & 0,25 & 1,9 & a)s & 0,25 & Q19 & 1,00 & 8,7 & 8,62 \\
\hline $\mathrm{m}$ & & & & & & & & & & & & & & & & & & & & & & & \\
\hline $\mathbf{2}$ & 1,48 & $0, \pi$ & 2,41 & 1,47 & & 0,26 & 0.53 & 1,67 & 1,00 & 0.96 & 0,42 & 0,5 & 0.54 & ast & 0,25 & 027 & 1,45 & ase & Q.4 & 1,58 & 300 & 1,51 & 1,36 \\
\hline MT & 4,26 & 2,78 & 7,84 & 721 & 7,62 & 2,99 & 1,97 & 7,76 & 3,84 & 4,48 & & 0,15 & 1,66 & 1,77 & 0,0 & 1,02 & & & 3,02 & 0,132 & 7,47 & 569 & 496 \\
\hline HM & 2,00 & 0,06 & & & ast & 3,69 & 1,46 & & & & 1,12 & & & & & & 3,38 & 0,33 & 9,56 & 0,40 & & & \\
\hline AP & & 9,43 & 2,14 & & 9,49 & & 1,11 & 0,29 & 0,2 & 0,24 & 0,24 & $0 \times 6$ & 0,10 & $a, 4$ & Q24 & 0,24 & 0,04 & 0,24 & 0,24 & 0,24 & 1,68 & $0 \leq 3$ & 0,24 \\
\hline $\mathbf{T N}$ & & & & & & & & & & & 0,75 & & & & & & & & & & & & \\
\hline $\mathbf{E d}$ & & & & & & & & & & & & & & & & & 0,29 & 0,14 & & & & & \\
\hline
\end{tabular}

João têm cor verde-escura e granulação variável de grossa a fina, em função da intensidade da deformação milonítica. Ao microscópio, possuem textura granular idiomórfíca a hipidiomórfica, porfirítica, de granulação grossa. Texturas poiquilítíca e cumulus são conspícuas. A deformação milonítica gera milonitos e ultramilonitos com fenoclastos de anfíbólio. Os minerais essenciais são augita e pargasita. Gorita, títanita, andesina/labradorita, opacos, apatita, epídoto, biotita e rara forsterita são acessórios.

Nos exemplares com deformação milonítica, a matriz é recristalizada, orientada e contém fenoclastos de anfibólio onde, por vezes, observam-se restos de piroxênio original. Em estágio de deformação mais avançada, os fenoclastos são raros e a matriz milonítica consiste de hastingsita, titanita, andesina (An 30), raro quartzo e clorita magnesiana. Em amostras com deformação extrema podem ocorrer fenoblastos de hastingsita. Um bandamento milonítico sutil pode ser observado por pequenas diferenças de granulação e variações na quantidade de plagioclásio. Vêmilas de quartzo e/ou albita recortam localmente as rochas da Suíte Fazenda São João e podem ser tanto concordantes quanto oblíquas à matriz orientada.

As características petroquímicas das rochas da Suíte São
João e sua comparação com rochas básicas, pertencentes a outras unidades estratigráficas da região, foram descritas e interpretadas por Brod \& Jost (1989). Estas rochas possuem $\mathrm{SiO}_{2}$ variável de 44,19 a $49,66 \%$ (Tab. 2), e mostram marcantes diferenças composicionais com relação a outras rochas básicas que ocorrem no lineamento. As proporções de $\mathrm{TiO}_{2}$ e $\mathrm{P}_{2} \mathrm{O}_{5}$ são relativamente altas e o $\mathrm{MgO}$ mostra comportamento anômalo, tendendo a aumentar com o incremento de $\mathrm{SiO}_{2}$, uma feição geoquímica ainda não compreendida. As proporções de $\mathrm{Al}_{2} \mathrm{O}_{3}$ são baixas. No tocante aos elementos menores, a Suíte Fazenda São João possui alto $\mathrm{Cr}$, Ni e Sr.

A composição normativa reflete o comportamento anômalo do $\mathrm{MgO}$, com rochas quartzo-normativas dando lugar a olivina-normativas com o aumento de $\mathrm{SiO}_{2}$.

A variação composicional dos anfibolitos da Suíte Fazenda São João é compatível com toleítos ricos em ferro. As proporções de elementos imóveis são similares às dos basaltos alcalinos. A razão $\mathrm{Y} / \mathrm{Nb}$ das rochas da Suíte Fazenda São João varia de 1 a 3 e é intermediária entre rochas alcalinas e toleíticas (Pearce \& Carm 1973). Estas rochas possuem, em geral, razão $\mathrm{Na}_{2} \mathrm{O} / \mathrm{K}_{2} \mathrm{O}$ semelhante a dos toleítos do Hawaí (Myiashiro 1975), mas a soma dos álcalis é pouco menor. Sua 


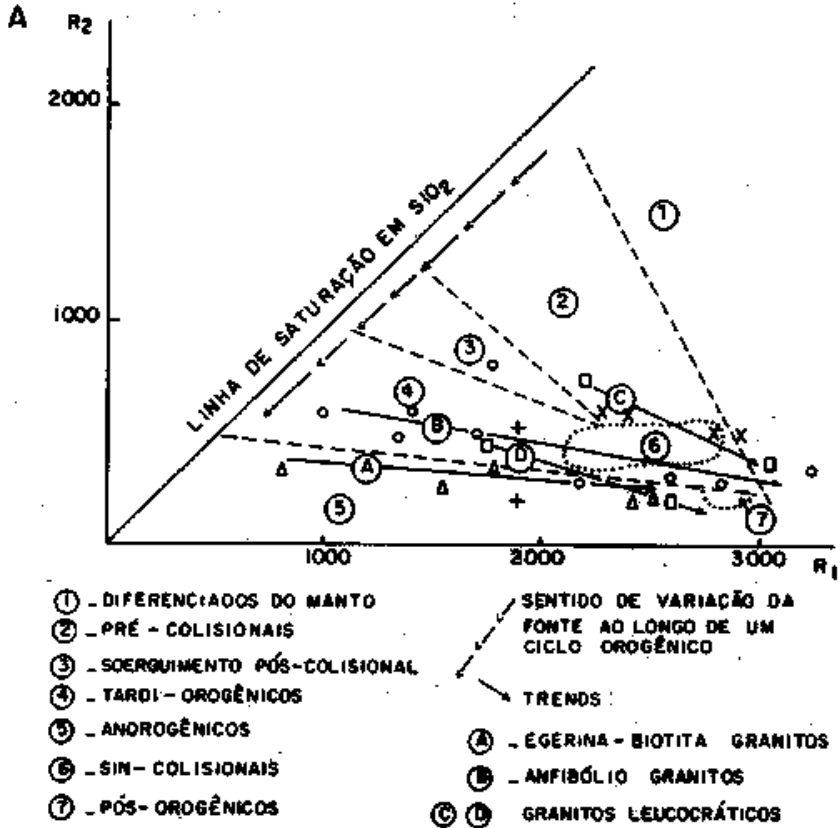

C

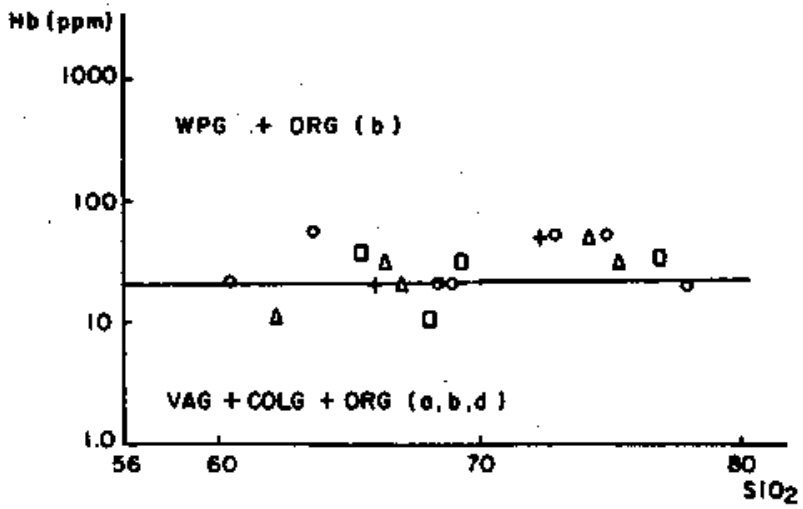

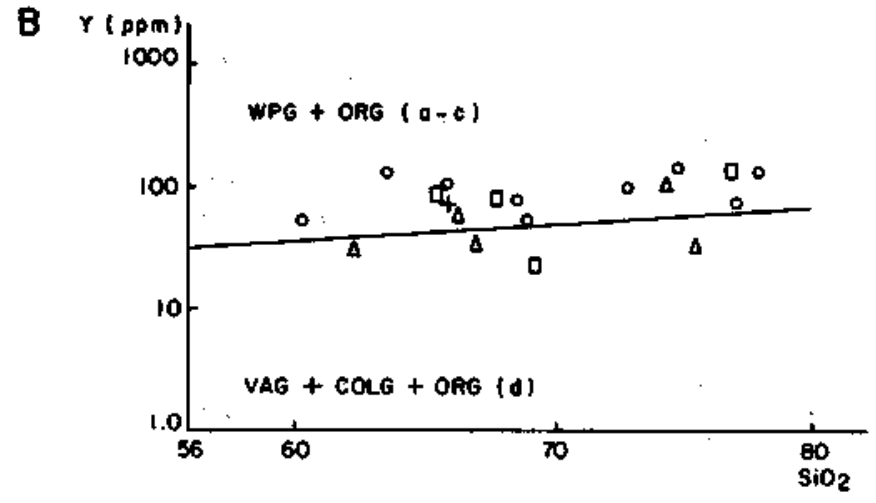

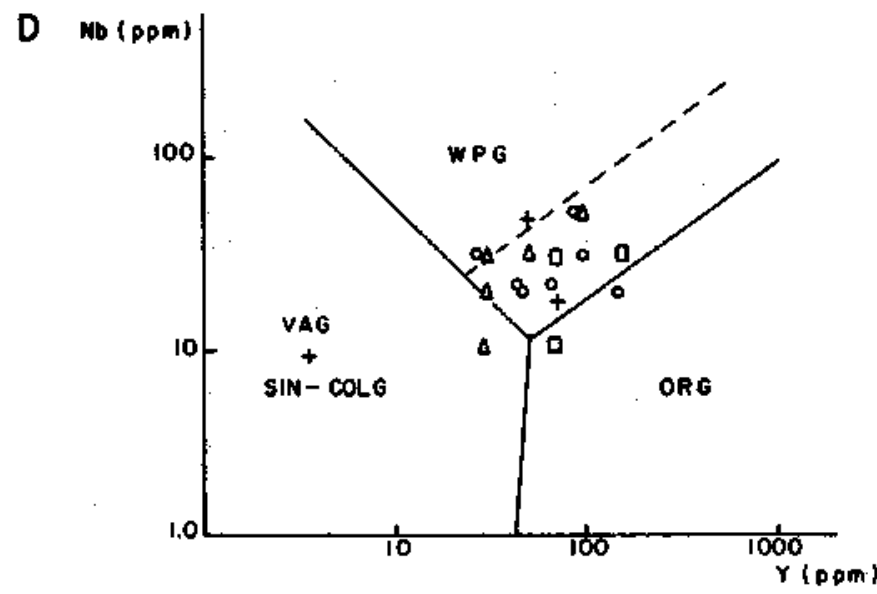

Figura 9 - Classificação geotectônica dos granitos da Suíte Baunilha de acordo com suas propriedades químicas. Diagramas de a. Batchelor \& Bowden (1985), b, c e d. Pearce et al. (1984). Símbolos como na figura 8

Figure 9 - Geotectonic classification of the Baunilha Suite granitoids, with respect to their chemical properties. Diagrams from a. Batchelor $\&$ Bowden (1985), b, c and d. Pearce et al. (1984)

razão Ti/V permite interpretá-las como basaltos continentais ou basaltos de ilha oceânica (Shervais 1982).

CONCLUSÕES A Zona de Cisalhamento do Rio Traíras é uma zona de deformação dúctil cuja ocorrência está confinada aos limites do Bloco de Niquelândia, sendo hoje apenas um segmento de uma estrutura maior no passado. A zona de cisalhamento, na porção preservada e estudada atua como limite tectônico entre o Complexo de Niquelândia e a seqüência vulcanossedimentar a oeste (Seqüência Coitezeiro), proporcionando o desacoplamento completo entre estes segmentos crustais.

A Zona de Cisalhamento do Rio Traíras tem forma linear, encurvada na extremidade sul, direção geral nordeste, mergulho subvertical e movimento modal transcorrente dextrógiro. As rochas que a caracterizam são milonitos generalizadamente recristalizados para blastomilonitos. As características petrográficas dos milonitos dependem amplamente da composição mineral e da textura de seus protolitos; amplas passagens entre os diversos protolitos e os milonitos podem ser reconhecidas. O metamorfismo dinâmico é variável ao longo da zona de cisalhamento, atingindo, em condições extremas, a zona da sillimanita da faties anfibolito e contrastam com as do metamorfismo regional da Seqüência Coitezeiro e do Maciço de Niquelândia.

Duas suítes intrudem o lineamento. Uma consiste de pequenos plútons intermediários a ácidos, de tendência alcalicálcica a alcalina, mostrando afinidade com granitos intraplaca e de cadeia mesoceânica. A outra está representada por diques de rochas básicas, em geral com textura cumulada, tendência toleítíca de alto ferro, mostrando afinidade com basaltos alcalinos intraplaca ou de ilhas oceânicas.

Agradecimentos Os autores agradecem à Metais de Goiás SÁ. - METAGO, pelo apoio de campo e de laboratório para a realização da Dissertação de Mestrado do autor senior e da qual este trabalho foi originado. Os agradecimentos são extensivos ao Conselho Nacional de Desenvolvimento Científico e Tecnológico - CNPq, pelas Bolsas de Pesquisa de que os autores são beneficiários (Processos 310.340/84.5 e 301.411/86.7). A Tereza Cristina Borges Junqueira pela revisão do manuscrito. 
Tabela 2 - Suite Fazenda São João - óxidos de elementos maiores (\% em peso), menores e norma CIPW (\% em peso)

\begin{tabular}{|c|c|c|c|c|c|c|c|c|c|c|c|c|c|c|}
\hline AMogr 1 & 54 & 5 & 56 & $n$ & 5 & 3 & 60 & 61 & 6 & 6 & 64 & 65 & 66 & 67 \\
\hline $\mathrm{son}$ & 4,19 & $4, \overline{23}$ & 44,93 & 45,45 & 46,00 & 46,50 & 44,70 & 46,82 & 47,05 & 4992 & 48,30 & 48,56 & 4,83 & 4,86 \\
\hline $\mathbf{T O}_{2}$ & 291 & 2,28 & 202 & 2,00 & 2,00 & 1,58 & 2,41 & 2,58 & 1,0 & 1,98 & 1,49 & 1,76 & 1,70 & 251 \\
\hline Alos & 11,9 & 1203 & 1159 & 11,35 & 766 & 9,92 & 939 & 80 & 11,16 & 7,65 & 102 & 7,65 & 7,14 & 694 \\
\hline $\mathrm{FeO}_{4}$ & 5 & 4,02 & 6,24 & 7,0 & 10,55 & 4,90 & 3,36 & 3,96 & 5,14 & 502 & 365 & 6018 & 600 & 3,84 \\
\hline $\mathbf{F O O}$ & 7,14 & 3,94 & 5,57 & 5,53 & 6,12 & 4,35 & 6,56 & 8,67 & 5,26 & 5,39 & 4,30 & 5,21 & 5,01 & 7,14 \\
\hline$a \infty$ & 15,94 & 16,39 & $\$ 5,87$ & 15,12 & 13,73 & $\mathbf{1 6 , 5 9}$ & 13,19 & 12,00 & 14,92 & 16,99 & 17,34 & 13,12 & 12,73 & 13,27 \\
\hline Mo & 8,20 & 8,76 & 1001 & 9,61 & 8,74 & 11,93 & 1390 & 11,60 & 9,AS & 11,39 & 1296 & 15,09 & 14,60 & 12,93 \\
\hline Nio & 0,16 & 0,43 & 0,18 & 0,11 & 0,25 & 0,14 & 0,13 & 0,17 & 0,12 & 0,18 & 0,13 & 0,12 & 0,12 & 0,15 \\
\hline $\mathrm{N}=\mathrm{O}$ & 1,00 & 0.73 & 298 & ax4 & $1, \mu$ & 0,09 & 1,05 & 1,4 & 124 & 104 & 1,19 & 1,0 & 1.13 & 106 \\
\hline BNo: & 0,36 & 0,65 & 0,25 & 0,40 & 0,18 & 0,36 & 0,46 & 0,35 & 0,4 & 0,22 & 0,30 & 0,17 & 0,20 & 0,19 \\
\hline PP. & 1,27 & $0 \leqslant 0$ & 1,51 & 1,60 & $0 / 5$ & 1,85 & 1,50 & 1,26 & $1 / 10$ & $|A|$ & 1,30 & 1,90 & 1,05 & $1, M ?$ \\
\hline Tond & 90,19 & 9,10 & 9943 & $99, \pi$ & 98,71 & 99,49 & 9925 & 99,13 & 99,08 & 99,3 & 99,39 & $10 \mathrm{~L}_{1} 33$ & 99,72 & 99,02 \\
\hline$a$ & 330 & 10 & 12 & 145 & 30 & 10 & 10 & 8 & 140 & 15 & 10 & 10 & s & is \\
\hline $\mathbf{F}$ & 29 & & 24 & 10 & & 10 & 15 & 17 & 10 & 19 & 10 & s & 5 & 20 \\
\hline 7 & $\boldsymbol{0}$ & 15 & 80 & 20 & 35 & 20 & 40 & $x$ & 25 & 4 & 23 & 15 & 15 & 75 \\
\hline $\mathbf{N}$ & 136 & 20 & $n 73$ & 30 & . $\$$ & 35 & 160 & 256 & 40 & s11 & $\boldsymbol{\omega}$ & 40 & 40 & 23 \\
\hline$\alpha$ & 126 & 50 & 70 & 45 & 160 & 200 & 320 & 30 & $\boldsymbol{6}$ & 90 & 290 & 150 & 150 & 123 \\
\hline $\mathbf{z}$ & & LSO & & $\boldsymbol{x}$ & 50 & 30 & 70 & & $\boldsymbol{x}$ & & 50 & $\mathbf{3 0}$ & 50 & \\
\hline $\mathbf{m}$ & & 10 & & 15 & 10 & 10 & 10 & & 10 & & 10 & 10 & 10 & \\
\hline $\mathbf{Y}$ & & 30 & & 15 & 20 & 15 & 20 & & 20 & & $x$ & 10 & 10 & \\
\hline B & & 50 & & 20 & 30 & 20 & 20 & & 20 & & 20 & 20 & 20 & \\
\hline$s x$ & & 1000 & & 700 & 300 & 500 & 100 & & 700 & & 300 & 100 & 130 & \\
\hline $\mathbf{v}$ & & 150 & & 200 & 300 & 150 & 150 & & 150 & & 150 & 150 & 150 & \\
\hline 0 & $1, \pi$ & 3,25 & 0,93 & 400 & & & & & $0 x 7$ & & & & & 3,69 \\
\hline on & $1, \pi$ & $1, A 7$ & 1,73 & 2,24 & 2.61 & 2,42 & 3,63 & 2,11 & 3,00 & 1,45 & 2,47 & 2,98 & $2,7 \mathrm{t}$ & 159 \\
\hline$A B$ & 1,2 & 6,39 & 8.66 & 6,59 & 12,50 & 8,12 & 14,28 & 12,45 & 10,76 & 8,9 & 127 & 12,12 & $9, \pi 8$ & 9,16 \\
\hline AN & 27,41 & 29,86 & 27,58 & 27,50 & 13,51 & 209 & 1681 & 16,37 & 24,85 & 1503 & 15,64 & 12,58 & 13,35 & 13,69 \\
\hline D & 4098 & 36,86 & 41,23 & $\mathbf{3 7 , 0 0}$ & 44,93 & 9,57 & 37,09 & 36,14 & 38,33 & $34,7 x$ & 55,30 & 41,31 & 3 & 41,41 \\
\hline frY & 4,30 & 4,57 & 6,93 & 7,80 & 12,65 & 293 & 701 & 18,46 & 12,56 & 8,73 & 0,99 & 10,84 & 2,64 & 19,47 \\
\hline $\mathbf{B N}$ & 4,21 & 4,57 & 6,93 & $n, 83$ & 785 & 2,13 & 6002 & 14,51 & 9,8 & 7,07 & ast & 8,79 & 18,31 & 16,38 \\
\hline FB & 900 & & & & 4,80 & $0 \leq 0$ & 099 & 1,56 & 2,07 & 1,65 & 0,2 & 2,06 & 4,3333 & 309 \\
\hline$\alpha$ & & & & & 1,16 & كرئ & 996 & 1,97 & & 0,73 & 7,29 & 11,60 & 3,16 & \\
\hline Fo & & & & & 0,0 & 655 & 8,44 & 1,52 & & 0,52 & 636 & 9.25 & 2,51 & \\
\hline FA & & & & & 0,42 & 1,48 & 1,53 & Q.45 & & 0,15 & 0,93 & 2,30 & 0,65 & \\
\hline
\end{tabular}

Obs.: as amostras consistem de gabros, hornblenditos e milonitos básicos de granulação fina.

\section{REFERÊNCIAS BIBLIOGRÁFICAS}

ALMEIDA, F.F.M. 1968. Evolução tectônica do centro-oeste brasileiro do Proterozóico Superior. Anais Acad bras. Ciênc, 40(Supl.):285-295.

ANGEIRAS, A.G. 1968. A faixa de serpentinitos na região central de Goiás. Anais Acad. bras. Ciênc., 40(Supl.):129-136

BARBOSA, A.L.M. 1968. Ambiente geológico das jazidas Niquelíferas de Niquelândia, Goiás. Li: Semana de Estudos Geológicos, 7. SICEG, 7:79-89

BATCHELOR, R.A. \& BOWDEN, P. 1985. Petrogenetic interpretation of granitoide rock series using multicationic parameters. Chem. Geol, 48:43-55.

BIRD, G.W. \& FAWCETT, JJ. 1973. Stability relations of Mg-chloritemuscovite and quartz between 5 and 10 kilobars water pressure. $J$. Petrol., 14:415-428.

BRÓD, J.A. 1988. Geologia das Rochas Vulcano-sedimentares da Região de Indaianópolis, Goiás, e Lineamentos Adjacentes. Brasília. 267p. (Dissertação de Mestrado, IG/UnB).

BROD, JÁ. \& JOST, H.1989. Geoquímica das rochas da porção oeste do Complexo de Niquelândia e seu significado geotectônico - Geochim. Brasiliensis, (no prelo).

BROWN, G.C. 1981. Space and time in granite plutonism. Phil. Trans. Soc. London, A301:321-336.

COSTA, LA.M. \& ANGEIRAS, A.G. 1971. Geosynclinal evolution and tectonic zoning of the Epi-Baykalian platform of Central Brazil. Geol Rundschau, 6 0(3): 1024-1050

DANNI, J.C.M.; FUCK, RA.; LEONARDOS, O.H. 1982. Archean and Lowe Proterozoic Units in Central Brazil. Geol. Rundschau, 71(1):291-317.

De La ROCHE, H.; LETERRIER, J.; GRANDCLAUDE, P.; MARSHAL, M. 1980. A classification of volcanic and plutonic rocks using R1-R2Diagram and major element analysis - its relationship with current nomenclature. Chem. Geol, 29:183-210.

GANGULY, J. 1969. Chloritoid stability and related paragenesis: theory, experiments, and applications. Am. Jour. Sci., 267:910-944.

GANGULY, J. 1972. Staurolite stability and related paragenesis: theory, experiments and applications. J. Petr., 13:335-365.
HOLDAWAY, M.J. 1971. Stability of andalusite and aluminum silicate phase diagram. Am. Jour. Sci., 2 71:97-131.

HOSCHECK, G. 1969. The stability of staurolite and chloritoid and their significance in metamorphism of pelitic rocks. Contrib. Min. Petr., 22:208-232.

HSU.L.C. 1968. Selected phase relationships in thesystemAl-Mn-Fe-Si-O: A model for garnet equilibria. J. Petr. 9:40-83.

LUTH, W.C.; JAHNS, R.H.; TUTTLE, O.F. 1964. The granite system at pressures of 4 to 10 Kilobars. J. Geoph. Res., 69:759-773.

MYIASHIRO, A. 1975. Classification, characteristics and origin of ophiolites. J.Geol,83(2):249-281.

NASCIMENTO, F.S.; VELOSO, F.D.L.M; SABÓIA, LA. 1981. Caracterização e discussão sobre a Seqüência Vulcano-Sedimentar da Borda Oeste do Maciço de Niquelândia (W do Rio Traíras). In: SIM P. GEOL CENTRO-OESTE, 1. Goiânia, 1981. Atas... SBG, Goiânia, p. $470-492$.

NEWTON, R.C. 1966 . Kyanite-andalusite equilibrium from 700 to $800^{\circ} \mathrm{C}$. Science, 153:170-172.

PEACOCK, MA. 1931. Classification of igneous rocks. J. Geol., 39:54-67.

PEARCE, JA. \& CANN, J.R. 1973. Tectonic setting of basic volcanic rocks determined using trace element analysis. Earth Planet. Sci. Lett., 19:290-300.

PEARCE, JA.; HARRIS, N.B.W.; TINDLE, A.W. 1984. Trace element discrimination diagrams for the tectonic interpretation of granitic rocks. $J$. Petr.,25(4):956-983.

RIBEIRO, W., F \& TEIXEIRA, NA. 1980. Seqüência Vulcano-Sedimentar da Borda W dos Complexos de Niquelândia e Canabrava. Boi. Inf., $S B G / N C O, 10: 33-88$.

RICHARDSON, S.W. 1968. Staurolite stability in a part of the system Fe-AlSi-O-H.J. Petr., 9:467-488

RICHARDSON, S.W.; GILBERT, M.C.; BELL, P.M. 1969. Experimental determination of kyanite-andalusite and andalusite-sillimanite equilibria: the aluminum silicate triple point Am. Jour. Sci., 267:259-272. 
RIVALENTI, O; GIRARDI, VA.V.; SINIGOI, S.; ROSSI, A.; SIENA, F. 1982. The Niquelândia mafic-ultramafic Complex of Central Goiás, Brazil: petrological considerations. Rev. Bras. Geoc. 12(1-3):380-391.

ROGERS, J.J.W. \& GREENBERG, J.K. 1981. Trace elements in continentalmargín magmatísm. Part II Alkali granites and their relationships to cratonization. Summary. Geol. Soc.Am. Bull.,92(1):6-9.

SEIFERT, F. 1970. Low temperature compatibility relations of cordierite in haplopelites of the system $\mathrm{K}_{2} \mathrm{O}-\mathrm{MgO}-\mathrm{Al}_{2} \mathrm{O}_{3}-\mathrm{SiO}_{2}-\mathrm{H}_{2} \mathrm{O}$. J. Petr., 11:7399.

SHERVAIS, J.W. 1982.11-V plots and the petrogenesis of modern ophiolitic lavas. Earth Planet. Sci. Lett., 59:101-118.
WINKLER, RG.F. 1976. Petrogênese das Rochas Metamórficas. Porto Alegre, Edgard Blücher. 257p.

WRIGHT, J.B. 1969. A simple alkalinity ratio and its applications to question of non-orogenic granite genesis. Geol. Mag., 10ti(4):370-384.

MANUSCRITO A634

Recebido em 11 de dezembro de 1969 Revisão do autor em 2 de abril de 1990 Revisão aceita em 31 de maio de 1991 